\title{
Rare Earth Deposits of Africa
}

\author{
R.E. Harmer ${ }^{1}$ and P.A.M. Nex ${ }^{2}$ \\ ${ }^{1}$ Department of Exploration Geology, Rhodes University, P.O. Box 94, Grahamstown, 6140, South Africa. E-mail: j.harmer@ru.ac.za \\ ${ }^{2}$ School of Geosciences, University of the Witwatersrand, Johannesburg, South Africa.E-mail: Paul.Nex@wits.ac.za
}

DOI:10.18814/epiiugs/2016/v39i2/95784

Rare Earth Elements (REE) are a group of chemicallycoherent elements that are critical to a wide range of modern high technology applications and the critical strategic role of REE to the economic development of the U.S.A., European Union and Japan has been recognised. China holds a near monopoly over the supply of REE and REE products - accounting for around 95\% of the global supply in 2010. These factors triggered a rush to discover REE deposits and develop REE production outside of China.

At the beginning of 2015 there were 11 advanced REE projects on the African continent - projects on which formally defined resources had been published. This review represents the first compilation of the geology, style of mineralisation, size and character of these REE resources drawing on reports in the public domain.

\section{Introduction}

The Rare Earth Elements (REE) are critical to a wide variety of modern high technology applications that range from fibre optics, lasers, phosphors, speciality metal alloys, rechargeable batteries and catalysts in petroleum refining, to powerful permanent magnets that are used extensively in hybrid and electrical motor vehicles, wind turbines and modern weapons systems. They are also key enablers in the miniaturisation of hard drives and consumer electronics. In the second decade of the $21^{\text {st }}$ Century, China produces almost $95 \%$, and consumes $75 \%$, of the global production of rare earth metals. Uncertainty in supply of REE to non-Chinese producers, coupled with recognition of the critical strategic role of REE to the economic development of the U.S.A., European Union and Japan, triggered a rush in 2009-10 to find and develop REE deposits outside of China.

\section{REE Nomenclature/Classification}

In current commercial usage, the Rare Earth Elements (REE) refer to a group of chemically-coherent elements (see Table 1), that comprise the 14 stable lanthanoids ${ }^{1}$ from ${ }_{57}$ Lanthanum to ${ }_{71}$ Lutetium ( ${ }_{61}$ Promethium is unstable and does not occur naturally) plus the chemically similar Group IIIa elements ${ }_{21}$ Scandium and ${ }_{39}$ Yttrium. Formally, IUPAC (Connelly et al., 2005) referred to this group as the
Rare Earth Metals. At present, Sc seldom contributes meaningfully to the economics of an REE project and so, for the purposes of the deposits in this review, the REE represent the 14 lanthanoid elements plus yttrium.

For ease of discussion, it is useful to subdivide the REE into smaller groups by atomic number. Naming schemes have been haphazardly applied by companies developing new REE deposits outside of China: many having little formal rationale, most seem simply designed to boost the perceived value of the project(s) in the company's portfolio!

In terms of chemical attributes, the formally acceptable subdivision of the lanthanoids is on the basis of the distribution of $4 \mathrm{f}$ electrons in the atomic structure: the "Light Rare Earth Elements" (LREE), La through Gd, have no paired 4f electrons; whereas the "Heavy Rare Earth Elements" (HREE), Tb through Lu, have at least one paired $4 \mathrm{f}$ electron. While Yttrium has no $4 \mathrm{f}$ electrons at all, its chemical behaviour closely approximates that of Dy and Ho and, as such, it is classified as a HREE. Alternatively, it is useful to distinguish a "Medium REE" sub-group of the LREE comprising Sm through Gd, leaving La through Nd as "Light LREE". This distinction derives from the standard practice in the solvent extraction process used to separate and purify the individual rare earth metals: the absence of Promethium in natural materials creates a larger than usual change in chemical character between $\mathrm{Nd}$ and $\mathrm{Sm}$ and advantage is taken of this "gap" to split the REE solution into three: a "light" La-Nd group, a "medium" Sm-Gd group and a "heavy" Tb-Lu+Y group (illustrated in Table 1). Since 2012, the Chinese Government has applied this distinction when allocating export quotas and export levies for REE.

In industry, concentrations of the REE are usually expressed in the oxide form as this is the common nature of the traded product: in the text the abbreviation REO is used for "rare earth oxide" and grades are conventionally expressed as percent total REO contents, abbreviated to TREO (or \% TREO).

\section{Economic Geology}

It has become something of a cliché in industry announcements and reports that rare earths are not particularly rare: $\mathrm{Ce}$, the most naturally abundant REE, is more common in the Earth's Crust than copper $(\mathrm{Cu})$; while the least abundant REE, Lu, has similar crustal abundance to antimony, is slightly more abundant than silver (Ag) and bismuth (Bi), but orders of magnitude more enriched than either Gold $(\mathrm{Au})$ or the platinum group elements.

Being a coherent group of chemically- and hence geochemicallysimilar elements, individual rare earth elements do not form unique geological minerals. While REE ore minerals do preferentially

${ }^{1}$ IUPAC recommend that the popularly used collective name for these elements "lanthanides" be replaced by "lanthanoids" because: "The ending 'ide'normally indicates a negative ion, and therefore lanthanoid [is] preferred to lanthanide." (Connelly et al., 2005; p52) 
Table 1. The Rare Earth Elements and recommended nomenclature schemes

\begin{tabular}{|c|c|c|c|c|c|}
\hline $\begin{array}{l}\text { Rare Earth } \\
\text { Element }\end{array}$ & Symbol & $\begin{array}{l}\text { Atomic } \\
\text { Number }\end{array}$ & $\begin{array}{c}4 \mathrm{f} \\
\text { electrons } \\
\text { paired }\end{array}$ & Chemical & Metallurgical \\
\hline Lanthanum & $\mathrm{La}$ & 57 & $\mathrm{~N}$ & \multirow{7}{*}{ 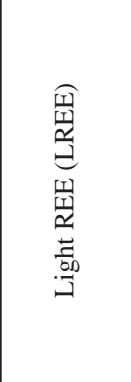 } & \multirow{4}{*}{ 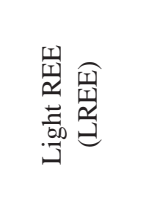 } \\
\hline Cerium & $\mathrm{Ce}$ & 58 & $\mathrm{~N}$ & & \\
\hline Praseodymium & $\operatorname{Pr}$ & 59 & $\mathrm{~N}$ & & \\
\hline Neodymium & $\mathrm{Nd}$ & 60 & $\mathrm{~N}$ & & \\
\hline Promethium** & $P r$ & 61 & $N$ & & \multirow{3}{*}{ 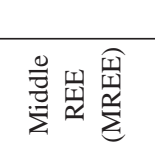 } \\
\hline Samarium & $\mathrm{Sm}$ & 62 & $\mathrm{~N}$ & & \\
\hline Europium & $\mathrm{Eu}$ & 63 & $\mathrm{~N}$ & & \\
\hline Gadolinium & $\mathrm{Gd}$ & 64 & $\mathrm{~N}$ & \multirow{9}{*}{ 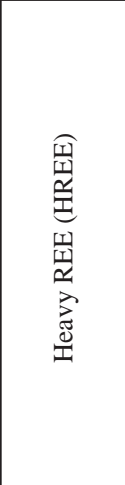 } & \multirow{9}{*}{ 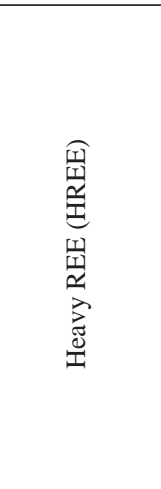 } \\
\hline Terbium & $\mathrm{Tb}$ & 65 & $\mathrm{Y}$ & & \\
\hline Dysprosium & Dy & 66 & $\mathrm{Y}$ & & \\
\hline Holmium & Ho & 67 & $\mathrm{Y}$ & & \\
\hline Erbium & $\mathrm{Er}$ & 68 & Y & & \\
\hline Thulium & $\mathrm{Tm}$ & 69 & Y & & \\
\hline Ytterbium & $\mathrm{Yb}$ & 70 & $\mathrm{Y}$ & & \\
\hline Lutetium & $\mathrm{Lu}$ & 71 & Y & & \\
\hline Yttrium & $\mathrm{Y}$ & 39 & - & & \\
\hline
\end{tabular}

** Promethium is radioactively unstable and is not found in natural materials.

concentrate specific REE, they always contain a mixture of the REE. The formulae for a selection of the more common RE minerals discussed in the text are listed in Table 2.

\section{REE enrichment processes}

A comprehensive discussion of rare earth element geochemistry and mineralisation processes is beyond the scope of the current review:

Table 2: A selection of important rare earth ore minerals mentioned in the text.

\begin{tabular}{|c|c|c|}
\hline Mineral & Formula & $\%$ REO $*$ \\
\hline Aeschynite & $\left(\boldsymbol{R} \boldsymbol{E}^{\ddagger}, \mathrm{Ca}, \mathrm{Fe}, \mathrm{Th}\right)(\mathrm{Ti}, \mathrm{Nb})_{2}(\mathrm{O}, \mathrm{OH})_{6}$ & 36 \\
\hline Allanite (orthite) & $\left(\mathrm{Ca}, \boldsymbol{R} \boldsymbol{E}^{\ddagger}\right)_{2}(\mathrm{Al}, \mathrm{Fe})_{3}\left(\mathrm{SiO}_{4}\right)_{3}(\mathrm{OH})$ & 30 \\
\hline Ancylite & $\mathrm{Sr}_{\boldsymbol{R}} \boldsymbol{E}^{\ddagger}\left(\mathrm{CO}_{3}\right)_{2}(\mathrm{OH}) \cdot \mathrm{H}_{2} \mathrm{O}$ & 46 \\
\hline Bastnaesite & $\boldsymbol{R} \boldsymbol{E}^{\ddagger} \mathrm{CO}_{3} \mathrm{~F}$ & 76 \\
\hline Burbankite & $(\mathrm{Na}, \mathrm{Ca})_{3}\left(\mathrm{Sr}, \mathrm{Ba}, \boldsymbol{R} \boldsymbol{E}^{\ddagger}\right)_{3}\left(\mathrm{CO}_{3}\right)_{5}$ & $\sim 9-23$ \\
\hline Cerianite & $(\mathbf{C e}, \mathrm{Th}) \mathrm{O}_{2}$ & 81 \\
\hline Churchite & $\mathrm{YPO}_{4} \cdot{ }_{2} \mathrm{H}_{2} \mathrm{O}$ & 44 \\
\hline Florencite & $\boldsymbol{R} \boldsymbol{E}^{\ddagger} \mathrm{Al}_{3}\left(\mathrm{PO}_{4}\right)_{2}(\mathrm{OH})_{6}$ & 32 \\
\hline Monazite & $\left(\boldsymbol{R} \boldsymbol{E}^{\ddagger}, \mathrm{Th}\right) \mathrm{PO}_{4}$ & 71 \\
\hline Parisite & $\mathrm{Ca} \boldsymbol{R} \boldsymbol{E}_{2}^{\ddagger}\left(\mathrm{CO}_{3}\right)_{3} \mathrm{~F}_{2}$ & 64 \\
\hline Synchisite & $\mathrm{Ca} \boldsymbol{R} \boldsymbol{E}^{\ddagger}\left(\mathrm{CO}_{3}\right)_{2} \mathrm{~F}$ & 51 \\
\hline Xenotime & $\mathrm{YPO}_{4}$ & 61 \\
\hline
\end{tabular}

Notes: REO*:\%TREO contained in mineral - either average of known typical compositions or stoichiometric estimate;

$\mathbf{R E}^{\ddagger}$ - site occupied by mix of rare earth elements (xenotime and churchite are predominantly Y; cerianite near exclusively of Ce so element shown rather than $\boldsymbol{R} \boldsymbol{E}^{\ddagger}$ ). interested readers are directed to recent reviews (and references cited therein) such as Linnen et al. (2014), Williams-Jones et al. (2012), Hoatson et al. (2011). A working classification is presented that covers the range of enrichment processes acting to produce the major REE deposits of Africa.

On average, the most REE-enriched magmatic rocks are carbonatites, followed by peralkaline granites and syenites. As a broad generalisation, enrichment of the REE to ore levels is the consequence of the incompatible behaviour of the REE during magmatic crystallisation and their limited solubility in low temperature aqueous solutions, making the REE largely immobile during weathering. Enrichment of the REE to potentially-economic ore grades generally requires the action of more than one geological process.

Enriching processes can be conveniently grouped, on the basis of the temperature range over which they operate, into Primary Magmatic, Magmatic/Hydrothermal and Epithermal.

\section{Magmatic}

Carbonatites are the most REE-enriched group of igneous rocks yet only one REE deposit is considered entirely magmatic: the Mountain Pass Deposit in the USA. Hyper-alkaline "agpaitic" (Edgar et al.,1974; Sørenson, 1999) syenitic rocks crystallise REE-enriched phases (such as eudialyte, loparite) that can be concentrated by cumulus processes during magmatic crystallisation to form "reef-like" economic REE deposits (e.g. Ilimaussaq; Lovozero). However, detailed mineralogical studies on these rocks have highlighted the significant influence of sub-solidus hydrothermal alteration on the final REE tenor in these minerals (e.g. Olivo and Williams-Jones, 1999; Mitchell and Liferovich, 2006).

In general, even the most enriched igneous rocks require the action of one or more secondary processes to produce economically significant grades of the REE.

\section{Magmatic/Hydrothermal}

Of the deposits in this review, all bar two are derived from carbonatites. The highest REE concentrations are typically encountered in iron-rich dolomitic carbonatite varieties: those with ferroan dolomite to ankerite as the main carbonate phase, sometimes accompanied by siderite.

The final stages of crystallisation of carbonatite magmas are fluidrich: the fluids being dominated by alkalis, halogens and $\mathrm{CO}_{2}-\mathrm{H}_{2} \mathrm{O}$. High fluid concentrations promote the growth of large crystals and the final stage of magmatic evolution can usefully be described as "pegmatitic" or pegmatoidal, by analogy with granitoid systems (e.g. Wall, 2004). The transition from fluid-rich magma to the subsolidus, crystals plus fluid-only, hydrothermal stage can be difficult to confidently define in carbonatites: Wall (2004) used the appropriate phrase "pegmatitic transition environment" for this stage. Burbankite (a sodium REE-Ba-Sr carbonate: Table 2) is recognised in several evolved pegmatoidal carbonatites where it always represents the earliest phase in any paragenetic sequence of REE ore minerals (Wall and Zaitsev, 2004; Wall, 2004). In the subsolidus hydrothermal stage, fluids react with the crystallised assemblage causing modification to mineralogy and texture, usually with associated enrichment in the REE. Burbankite is not stable under these conditions and is pseudomorphed by assemblages of alkali-free REE phases, such as ancylite and the fluorocarbonates along with baryte and strontianite. Large, hexagonal, 
relict burbankite crystals are recognised at the Wigu Hill (Figure 8), Kangankunde (Wall and Mariano, 1996) and Nkombwa (Figure 5) carbonatitic REE deposits discussed below. Wall (2004) argued that the disappearance/replacement of burbankite indicates the change from the pegmatitic stage to a fluid-dominated, potentially open-system, metasomatic stage of subsolidus mineralisation. Whether the metasomatic stage remains a closed system, with the fluid(s) remaining within the bounds of the crystallised intrusion, or becomes open with fluid(s) lost to the country rocks, can have a major influence on the relative concentrations of individual REE in the mineralised areas.

A characteristic feature of most carbonatite intrusions is the presence of a border zone - often extensive - where country rocks have been alkali metasomatised: these are termed "fenites", and the process, "fenitisation", is named after the first description of this phenomenon in the Fen Complex in Norway (Brögger, 1921). Any xenolithic material encountered within a carbonatite is also invariably fenitised. Depending on the composition of the fluid, and the nature of the country rocks, REE can be deposited into or leached from the fenites.

\section{Epithermal/Supergene}

Rare earth elements are effectively concentrated in residual deposits such as laterites produced by prolonged tropical weathering. In carbonatites chemical weathering causes the breakdown of the main carbonatite minerals: dissolution of the carbonate phases and apatite releases the REE, which are subsequently incorporated into new REE supergene phosphate and carbonate minerals such as monazite and/or bastnaesite. REE enrichments achieved in these residual deposits are typically 5-10 times those in the original source rock.

A special type of supergene residual deposit are the so-called REE ion-adsorption clays, first recognised and exploited in southern China, which have made a crucial contribution to China's near-monopolistic domination of the world rare earth market. In the southern Chinese deposits, deep weathering of granitic and acid volcanic rocks without associated denudation, has generated weathering profiles rich in clays. REE released during the breakdown of REE-bearing accessory phases in the protolith are adsorbed onto kaolinitic and halloysitic clay minerals and retained. Fractionation of the REE can occur during this process with the relative HREE concentration increasing with depth in the weathering profile (Chi and Tian, 2008; Bao and Zhao, 2008). It is estimated that residual REE clay deposits account for $80 \%$ or more of the world's HREE resources (Chi and Tuan, 2008). REE grades are usually extremely low in these deposits - typically 0.03 to $0.3 \%$ - and are of economic interest only because the REE can be extracted easily and cheaply. Extraction typically involves slurrying the clay with water in a pit lined with plastic sheeting. The addition of either sulphuric acid $\left(\mathrm{H}_{2} \mathrm{SO}_{4}\right)$, or ammonium sulphate, releases the REE from the clay minerals into the aqueous solution which is then decanted into a second lined pit. Addition of oxalic acid precipitates the REE as oxalates which are removed; roasting of the oxalates at $800^{\circ} \mathrm{C}$ drives off carbon dioxide and water, forming REE oxides which are bagged and sent for refining. The process, while unsophisticated, uses aggressive reagents and without adequate controls can cause extensive environmental damage.

REE-bearing accessory phases such as zircon, monazite and xenotime, are common in crustal granitoids and are refractory during weathering: as such they are a common constituent of heavy mineral sand placers. Prior to the 1980 s, placer deposits were the major source of REE supply. No REE are currently being produced from African placer deposits. Mineral sands mined by Richards Bay Minerals on the northern KwaZulu-Natal coast in South Africa contain a significant proportion of monazite but the high Th content of the monazite renders these placers unattractive as a source of REE at present.

\section{Review of African REE Deposits}

\section{Scope}

It is beyond the scope of the current review to deal with all known or researched cases of REE mineralisation in Africa. As discussed previously: REE are not particularly scarce elements in the Crust and can become enriched to ore levels by common geological processes: rare earth mineral resources - i.e. mineralisation with a "realistic prospect for eventual economic extraction" (The JORC Code, 2012 Edition; section 20) - are far less common.

The REE market is ever-growing but relatively small: global demand was just over 120,000 tonnes in 2014 with a total value of $\$ 3.76$ billion and is projected to grow to over 150,000 tonnes by 2020 having a value of between $\$ 8.25$ and $\$ 9.5$ billion (Adamas Intelligence, 2014). Demand for individual rare earth metals varies substantially and the projected growth is dominated by increased demand for Nd, Pr and Dy, relative to REE like La and Ce which will be progressively over-supplied.

China accounts for over $90 \%$ of the REE supply and this is projected to decrease to below $70 \%$ as non-Chinese sources of production enter the market by 2020. As of August 2015 there were 53 advanced rare-earth projects under development outside of China, on which 58 code-compliant (i.e. conforming to standards prescribed in JORC, SAMREC or NI43-101) rare-earth mineral resources had been defined; these were held by 49 companies located in 16 different countries (see Advanced Rare-Earth Projects Index maintained by Technology Metals Research - www.techmetalsresearch.com). These advanced, non-Chinese REE projects represent potential REE outputs that are many times the current and near future demand from nonChinese consumers. In addition to these advanced projects, there are as least as many prospects on which significant exploration has been completed. Consequently, there is little incentive for exploring for new REE deposits, unless they have highly unusual concentrations of the rarest of the high-demand REE in a form that is easily extracted.

For this reason, this review will be limited in scope to the African REE projects for which reporting code compliant resource statements are available - as at the start of 2015 there were 11 such projects. Two additional projects/prospects - the Nkombwa Hill carbonatite REEPhosphate deposit and the Gakara/Karonge vein REE deposit - that fall outside of this criterion, have been included for their historical and/or scientific/technical interest. Project locations are shown in Figure 1.

\section{Data Sources}

Where possible we have endeavoured to include only data that are in the public domain and limit referencing of unpublished internal company reports.

Of the 13 projects under review, 12 are (or have been) associated with listed public companies: 6 of these on the Toronto Stock Exchange (main TSX board or the venture capital TSX.V board), 3 with the Australian Securities Exchange (ASX), 2 on the Alternative 


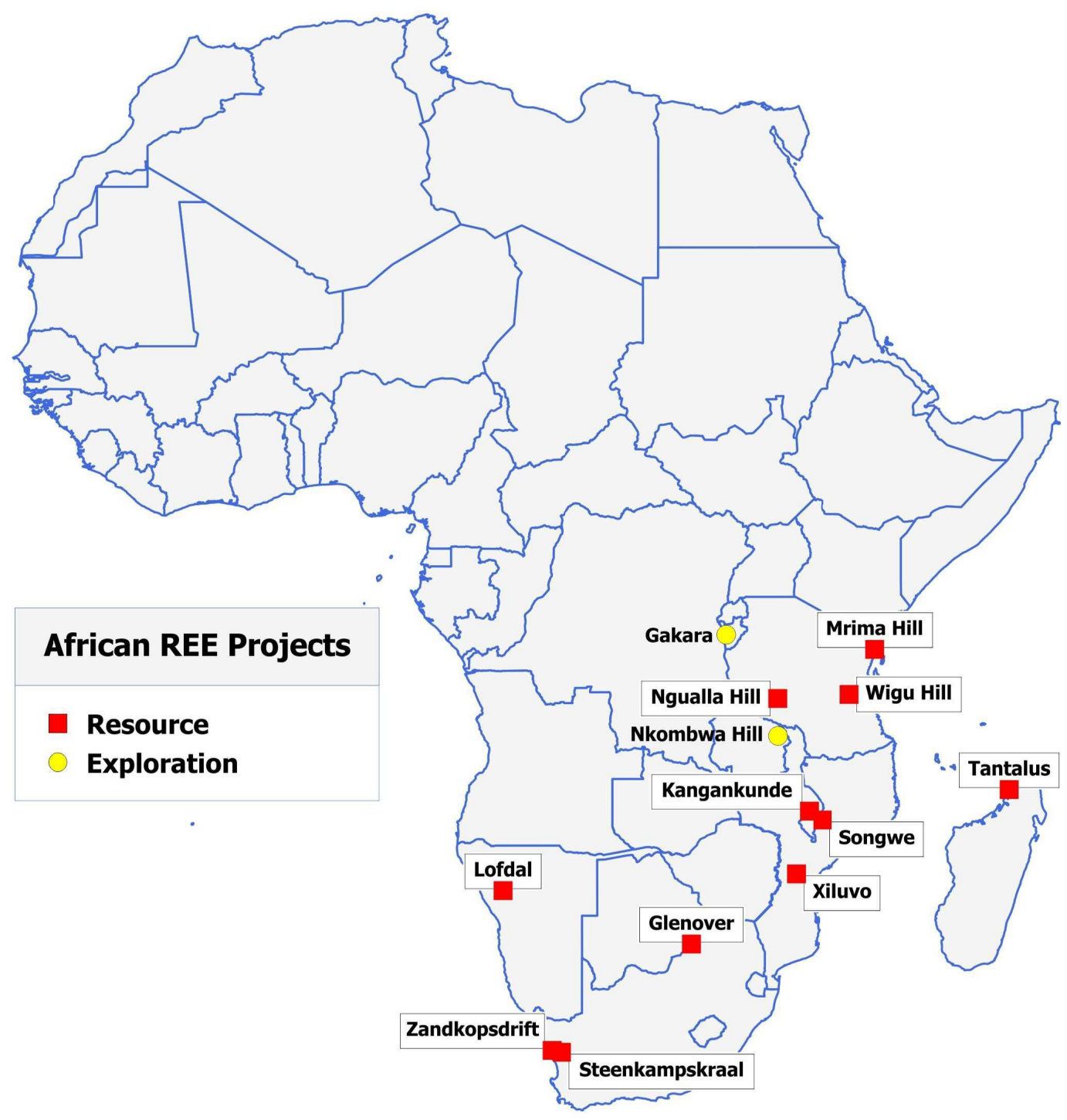

Figure 1: Map showing locations of the African REE projects included in the review.

Investment Market (AIM) of the London Stock Exchange and 1 on the Dusseldorf Stock Exchange. Companies reporting to the TSX are required to conform to the requirements of National Instrument 43101 (NI 43-101) and to file all reports with the System for Electronic Document Analysis and Retrieval (SEDAR) of the Canadian Securities Administrator: as such these reports are accessible to the public on the website $w w w . s e d a r . c o m$. The ASX requires all reporting to conform to the JORC (Joint Ore Reserves Committee) Code but has no requirement for complete technical reports to be lodged on their site, only company announcements and presentations. AIM does not prescribe a reporting code but requires that reports conform to either one of NI 43-101, JORC or SAMREC (South African) standards; it is even less prescriptive than ASX on what detail needs to be made public. As a consequence, far more detail is available for the TSXlisted company projects than those listed on other exchanges.

Where possible, referencing of company reports or announcements is accompanied by the URL where the document may be accessed (as of January 2015).

The deposits are ordered and grouped loosely according to mode of genesis.

\section{Kangankunde (Malawi)}

\section{Location and Ownership}

The Kangankunde carbonatite complex is situated south of Lake Malawi, approximately $75 \mathrm{~km}$ north of Blantyre (Figure 1). Kangankunde was dated at $123 \pm 6 \mathrm{Ma}$ (on phlogopite: Cahen and Snelling, 1966) and represents the most REE-enriched intrusion within the Cretaceous Chilwa Alkaline Province (Wall and Mariano, 1996).

Ownership of the mineral rights over Kangankunde is unclear: Lynas Corporation (ASX:LYC; www.lynascorp.com) claims 100\% title to a Mining License in their 2014 Annual Report but this is contradicted by a ruling of the Malawi High Court in 2010 preventing the transfer of the Mining License to Lynas (e.g. articles in Sydney Morning Herald [www.smh.com.au] November 10 and 14, 2011; The Nation [www.mwnation.com] 10 October 2013).

\section{Geology}

Kangankunde is one of several carbonatitic complexes in Malawi 
mapped by Magnus Garson for the Geological Survey of Nyasaland (now Malawi) between 1952 and 1963 and summarised in Garson (1966).

Kangankunde is oval in shape, $900 \times 750 \mathrm{~m}$ in size, and consists of a central core of carbonate-rich rocks surrounded by a rim of carbonatite agglomerate and feldspathic breccia (Figure 2). The complex was emplaced into Paleoproterozoic semi-pelitic gneisses that have been fenitised over distances of up to $1200 \mathrm{~m}$ from the carbonatite. Truly magmatic carbonate rocks comprise only a small proportion of the complex at the present erosion level.

Based on field evidence the earliest unit of the complex is a small plug and dykes of altered (carbonated) nephelinitic rock, misleadingly termed "apatite-beforsite" by Garson (1966). The outer annulus of fragmentary rocks was regarded as a volcanic vent-fill by Garson (1966) and is composed of brecciated fenite at the outer margin with strongly carbonated rocks forming the inner portions; carbonate-rich agglomerate occupies an intermediate zone. Agglomerates consist of angular blocks of feldspathic breccia, up to $0.5 \mathrm{~m}$ in diameter, set in a sparse matrix of iron-rich carbonates that contain manganese oxides in places. Phlogopite replacement of the feldspathic component is sometimes noted and the rock (matrix and clasts) is cut by veinlets of ankerite and phlogopite.

The main mass of the complex is made up of "carbonatised feldspathic rock", a heterogeneous and complex mixture of carbonated rocks ranging from slightly carbonated feldspathic types to carbonaterich types with only minor feldspar (Woolley, 2001). Large areas of

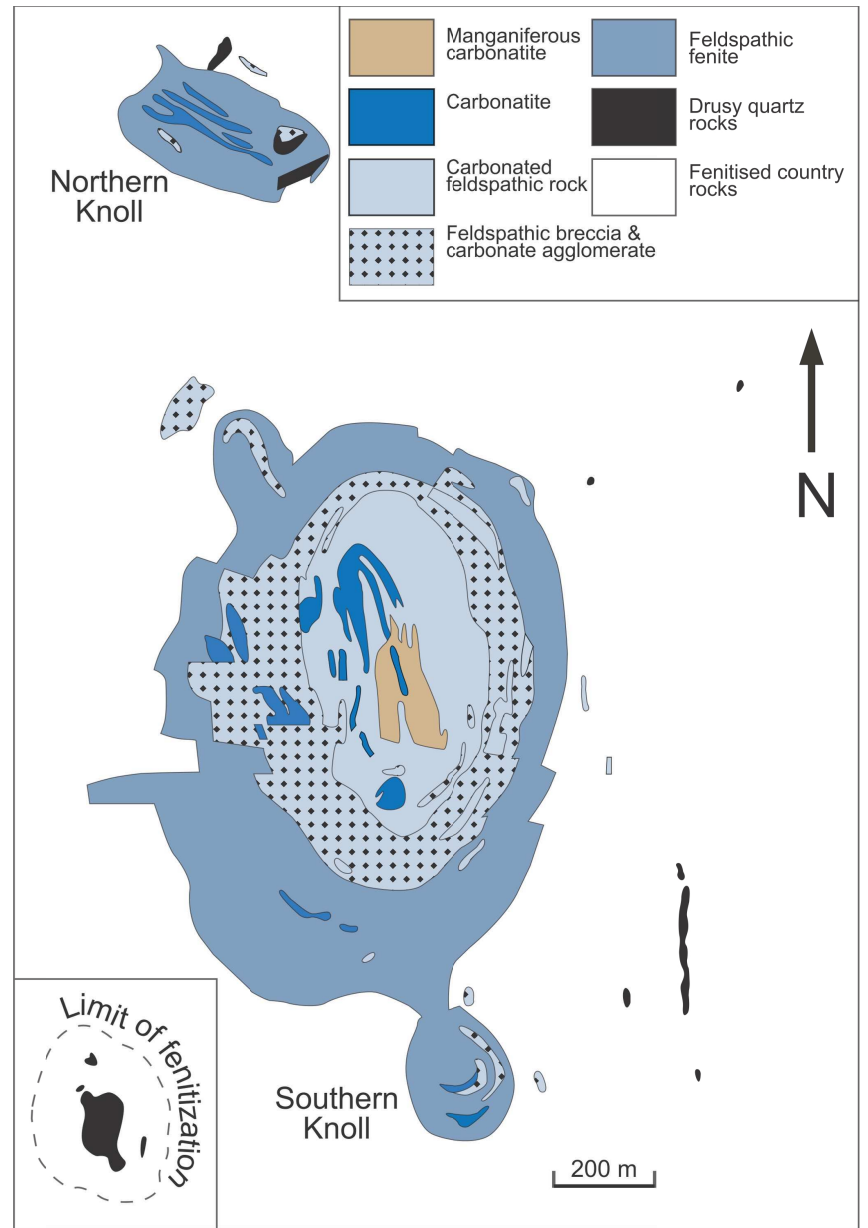

Figure 2: Geological map of the Kangankunde Carbonatite Complex (modified after Garson, 1966; Woolley, 2001). carbonated feldspathic rock became mobilised and have intruded the less carbonated types generating complex field relationships. The rock is typically red-brown and consists of varying proportions of feldspar and ankeritic carbonate with accessory iron oxides and monazite.

True carbonatites are found in the western and central parts of the complex as arcuate systems (stockworks?) of dykes and veins, with a plug-like intrusion of carbonatite mapped in the southern part of the central area (Garson, 1966; Woolley, 2001). Ferroan dolomite to ankerite carbonatites dominate (Wall and Mariano, 1996), along with siderite-ankerite types (Buckley and Woolley, 1990; Duraiswami and Shaikh, 2014). Mn-rich ankerite carbonatite underlies a zone in the central part of the complex from which emanates a ramifying network of dykelets (Woolley, 2001).

\section{Mineralisation}

REE mineralisation is pervasive within the true carbonatites and extends outwards into the fenitised and carbonated units as well. Pale-green monazite is the main REE-bearing mineral in the carbonatites, along with minor bastnaesite, florencite-goyazite and synchisite (Wall and Mariano, 1996). Monazite typically forms euhedral crystals up to $2 \mathrm{~mm}$ in size and occurs in a variety of textural forms: as "zones, bands and rounded bodies showing radiate structures" in mottled light to dark brown (ankerite?) carbonatites; and disseminated through dark brown and black (ankerite-siderite?) carbonatites (Holt, 1965). Duraiswami and Shaikh (2014) argued that the mineralisation was hydrothermal, and used the presence of collingsite $\left[\mathrm{Ca}_{2}(\mathrm{Mg}, \mathrm{Fe})\left(\mathrm{PO}_{4}\right)_{2} \cdot 2 \mathrm{H}_{2} \mathrm{O}\right]$ to deduce temperatures of $\sim 250-400^{\circ} \mathrm{C}$ for this.

\section{Resource}

No exploration investigations were completed on Kangankunde after the initial economic studies of Holt (1965) and the geological and process test work completed between 1987 and 1990 by the BRGM. Lynas Corporation purchased the BRGM geological and geochemical data (derived from more than 2,000 $\mathrm{m}$ of diamond core drilling and 550 trench samples) and had the data independently validated for a mineral resource estimate. This exercise defined an inferred resource, compliant with the JORC guidelines, of 2.53 million tonnes at an average grade of $4.24 \%$ REO for 107,000 tonnes of contained REO (Lynas, 2010; details in Table 4).

\section{Songwe (Malawi)}

\section{Location and Ownership}

The Songwe carbonatite is located south of Lake Chilwa, approximately $85 \mathrm{~km}$ east of Blantyre and close to the MalawiMozambique border (Figure 1). Lancaster Exploration Ltd., a wholly-owned subsidiary of Mkango Resources (TSX.V: MKA; www.mkango.ca), owns the exclusive prospecting license (EPL) over the property.

\section{Geology}

The Songwe carbonatite vent cuts the western margin of the large Mauze nepheline syenite intrusion (Woolley, 2001); both are members of the Chilwa Alkaline Province as evidenced by dates of 


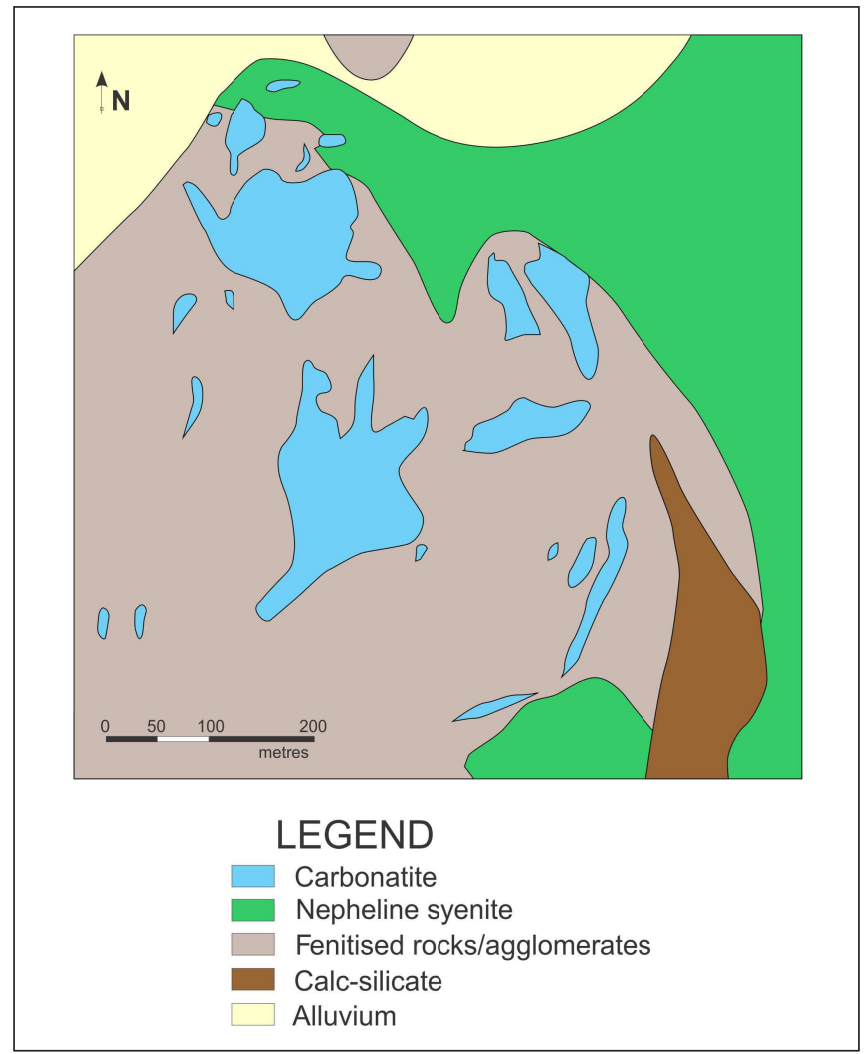

Figure 3: Simplified geological map of the Songwe Carbonatite (modified after Swindon and Hall, 2012).

140-130 Ma for zircon from both intrusions (LA-ICP-MS U-Pb: Broom-Fendley et al., 2014a).

Songwe is approximately $800 \mathrm{~m}$ in diameter, and composed of feldspathic breccia and agglomerate cut by arcuate carbonatite sheets (Figure 3). The carbonatites were emplaced in several pulses and range from early calcite-carbonatites to later ankerite-carbonatites and ultimately minor intrusions of "ferroan-carbonatite" (Croll et al., 2014). Proterozoic gneisses surrounding the complex have been metasomatised to potassic fenites. Late-stage phonolitic dykes have been recognised in drill-core (Swinden and Hall, 2012).

Calcite-carbonatites predominate and occur as irregular bodies of massive carbonatite emplaced in multiple stages. Early calcitecarbonatites contain calcite with minor apatite and zircon, while later varieties have $\mathrm{Fe}$ - and $\mathrm{Mn}$-rich calcites with ankerite and accessory apatite, $\mathrm{Fe}$ - and $\mathrm{Mn}$-oxides, pyrite, fluorite and K-feldspar (Swinden and Hall, 2012; Croll et al., 2014; Broom-Fendley et al., 2014a). Later ankerite-carbonatites occur as extensive thin dykes, veins and breccias and contain ankerite with accessory fluorite, calcite, REE-fluorocarbonates, pyrite and occasional quartz (Broom-Fendley et al., 2014a).

Breccias have diverse compositions but can be generalised as: (i) feldspar-rich breccias containing clasts and fragments of fenite, nepheline syenite and minor calcite carbonatite set in a Fe- and $\mathrm{Mn}$ oxide bearing carbonate matrix; and (ii) carbonate-rich breccia containing fragments of fine-grained calcite carbonatite and minor fenite in a fine-grained, carbonate-rich matrix (Swinden and Hall, 2014).

Adjacent fenites are pale-red and dominated by potash feldspar; more sodic varieties occur north of Songwe at Chenga Hill. It is thought that fenites at the top of Songwe Hill represent a roof zone to the carbonatite and contain black Fe- and Mn-rich carbonate veins (Swinden and Hall, 2012).

\section{Mineralisation}

Details of the Songwe REE mineralisation are derived largely from Swinden and Hall (2012). REE mineralisation occurs mainly in the carbonatite phases but extends into fenites and breccias as wellthe carbonatite component clearly controlling the enrichment levels. During the resource definition study the deposit was subdivided into three domains: carbonatite domain, fenite domain, and a mixed domain.

Pale-grey, fine-grained, calcite carbonatites predominate within the carbonatite domain. A zone of "black carbonatite" in the northeastern part of Songwe has the highest REE grades (average 3.8\% TREO) and comprises texturally complex black to light grey carbonatite with an abundance of cross-cutting dark Fe- and Mn-rich carbonatite veins.

REE mineralisation manifests as pervasive streaks of orange to pink rare earth fluorocarbonates and apatite. REE grades are lower in the fenite domain-typically less than $0.5 \%$ TREO-but elevated ( $1 \%$ TREO) where associated with carbonatite, particularly ferroan varieties. REE levels in the mixed domain are variable and reflect the relative proportions of carbonatite in the mix. Synchisite-(Ce) and apatite are the dominant REE ore minerals throughout the deposit and are commonly associated with strontianite and baryte. Synchisite occurs as clusters of 10-60 $\mu \mathrm{m}$ long acicular to lath-shaped crystals: aggregates can attain diameters of $400 \mu \mathrm{m}$. Apatite is generally recrystallized and occurs in veins (Al-Ali et al., 2014). LA-ICP-MS studies of the apatites define a progressive change in REE compositions from LREE rich in magmatic apatites in calcite carbonatites, to remobilised HREE enriched types in veins and stringers associated with iron-manganese oxides. Preliminary fluid inclusion studies suggest that secondary apatites formed at low temperatures of $300^{\circ} \mathrm{C}$ to $160^{\circ} \mathrm{C}$ (Broom-Fendley et al., 2014b). This is consistent with the REE mineralisation at Songwe being a largely post-magmatic feature associated with hydrothermal processes overprinting the magmatic assemblages (Swinden and Hall, 2012).

\section{Resource}

Mkango Resources reported a resource for the Songwe Project, following NI 43-101 guidelines, in September 2012 (Swindon and Hall, 2012). Each of the three mineralised domains were modelled separately with indicated and inferred category resources estimated for each. In 2014 Mkango reported a maiden Ore Reserve of 8.5 Mt at a grade of $1.6 \%$ TREO for 136 kilo tonnes (kt) of contained REO. Full details of the compound grades, tonnages and composition of the resource classification are presented in Table 4.

\section{Nkombwa Hill, Zambia}

\section{Location}

The Nkombwa Hill carbonatite complex, located in the Muchinga Province of north-eastern Zambia, lies within the Luangwa Valley rift segment of the western arm of the East African Rift system (Figure 1). Nkombwa has been dated at $679 \pm 25 \mathrm{Ma}$ (K-Ar: Snelling, 1962) and is one of a group of Precambrian carbonatites in the western limb 
of the East African Rift system that pre-date the Tertiary rifting event by hundreds of millions of years (others include Ngualla, Lueshe and Nachendezwaya: Woolley, 1989).

\section{Geology}

The complex is approximately $1.5 \times 1.0 \mathrm{~km}$ in size and underlies a steep-sided hill rising $300 \mathrm{~m}$ off the flat plains of the Luangwa valley floor. The intrusion is composite (Figure 4), built of several intrusive phases of magnesian carbonatite magma. Intrusive contacts and flow foliations in all carbonatite varieties are sub-vertically disposed. No magmatic silicate rocks have been found in the complex.

The earliest recognisable carbonatite phase is a relatively uniformtextured, grey- to buff-coloured, medium-grained dolomite carbonatite which makes up the bulk of the intrusion. Zones exist where the dolomite carbonatite is locally coarse-grained with carbonate rhombs attaining diameters of 3-5 cms; no change in the nature of the dolomite occurs and no additional phases are noted in these zones. Reaction between dolomitic magma and quartzo-feldspathic country rock gneisses has generated phlogopite-rich fenites. A semi-continuous marginal facies of phlogopite carbonatite and carbonatite breccia is found near the base of the Hill (effectively traced by the potassium channel of the radiometric survey over the complex). This carbonatite variety is clearly the product of entrainment of phlogopite from fenitised country rock.

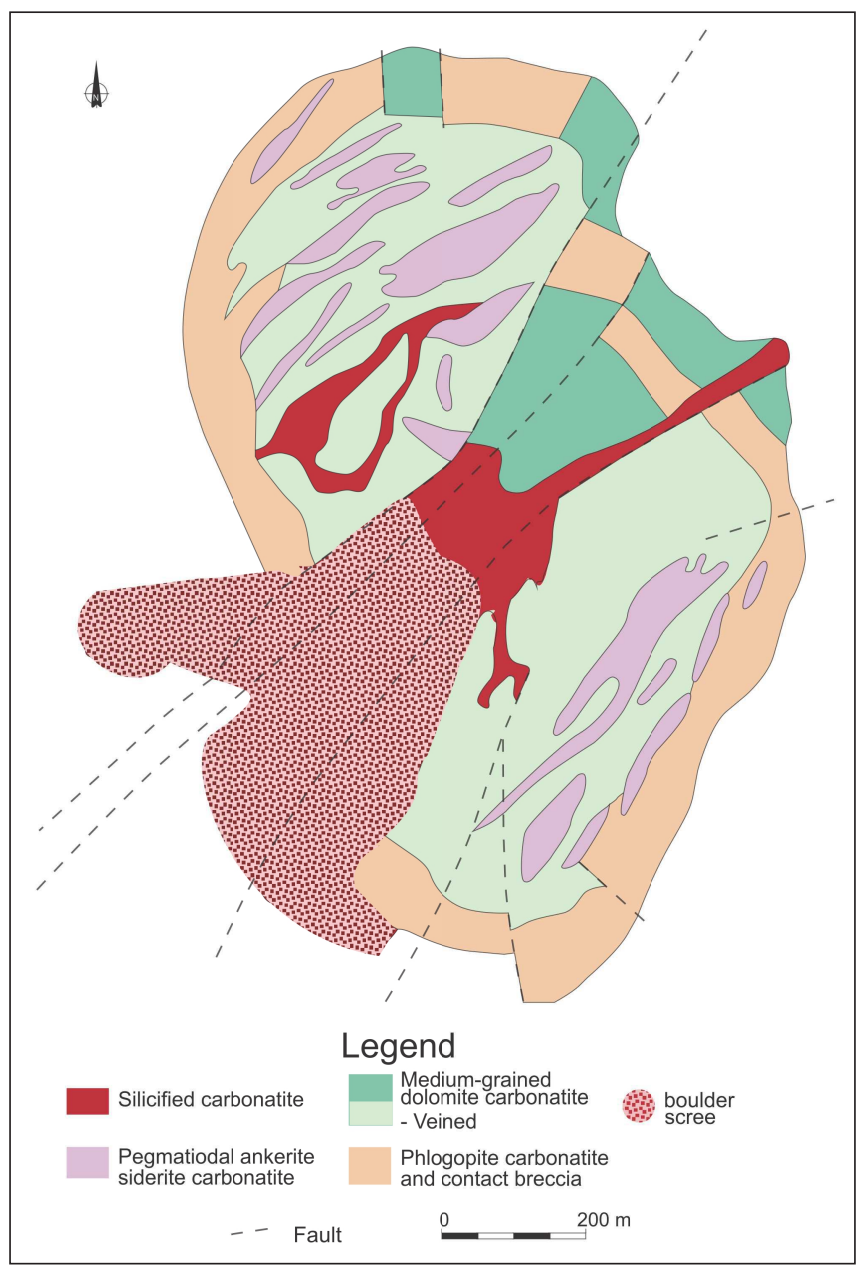

Figure 4: Geological map of the Nkombwa Hill Carbonatite Complex (modified after Turner et al., 1989).

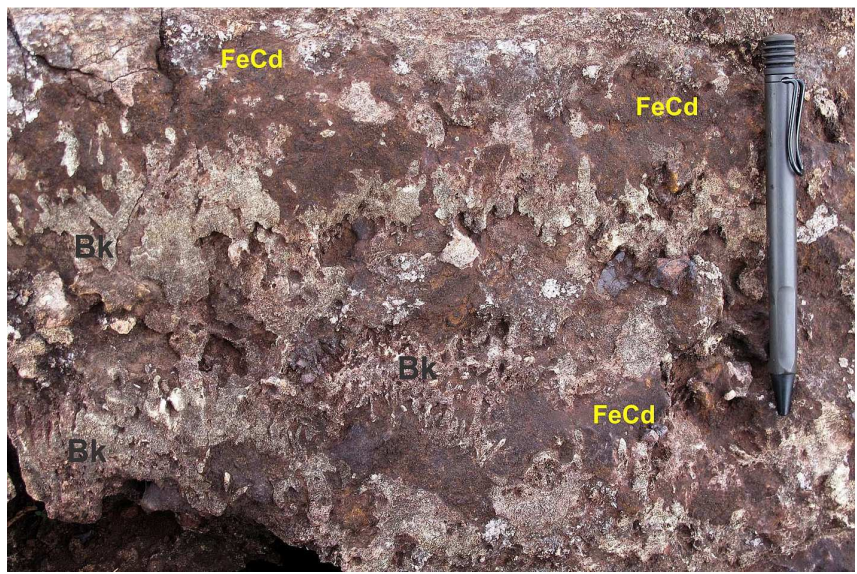

Figure 5: Pegmatoidal mineralised iron rich-dolomitic carbonatite: Nkombwa Hill. Clusters of relict burbankite megacrysts (Bk) set in dark brown ankeritic dolomite $(\mathrm{FeCd})$.

Vari-textured, coarse to pegmatoidal, iron-rich carbonatites occur as large lensoid- to sheet-like bodies within the dolomite carbonatites and are best exposed in the upper portions of the hill. Although generally concordant with the foliation in the earlier carbonatite, crosscutting relationships are sometimes seen suggesting these may represent a later intrusive phase. Carbonate minerals are iron-rich ankerites while dark, interstitial siderite is common (see Woolley and Buckley, 1993): the high iron contents render these rocks chocolateto grey-brown in outcrop. Crystals attain lengths of $8-10 \mathrm{~cm}$ but median sizes are 4-5 cm (Figure 5). Outcrops of the vari-textured carbonatite are characterised by open cavities ranging in size from $\mathrm{cm}$-scale vugs to cavities $10-15 \mathrm{cms}$ in diameter.

Iron-rich, cherty rocks (aptly described as "limonite stained chalcedony" by Turner et al., 1989) cap the central parts of Nkombwa Hill and represent a pervasive in situ silica replacement of the carbonatites, particularly the pegmatoidal type. It is possible to recognise many of the characteristic textural features of the pegmatoidal iron-rich carbonatites in these cherty rocks; remarkably, the cavities described above persist in the silicified products. Green grains of monazite are conspicuous and readily identifiable with the naked eye (Figure 6). The basal contact with the underlying carbonatite

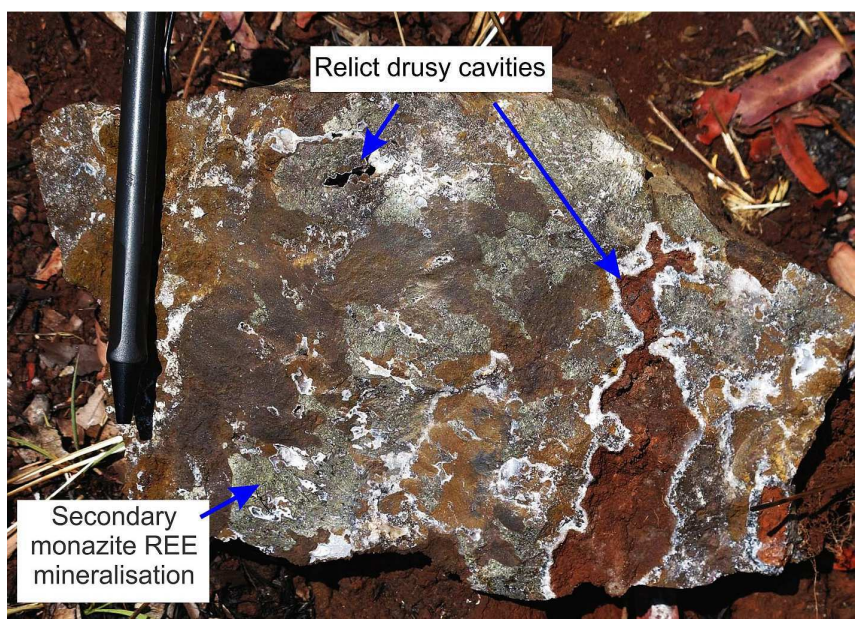

Figure 6: Silicified pegmatoidal carbonatite showing relict textures and high grade monazite REE mineralisation: Nkombwa Hill. Note the presence of cavities inherited from the original pegmatitic carbonatite. 
is undulating but essentially sub-horizontal with a gentle dip towards the east.

\section{Mineralisation}

The pegmatoidal, vari-textured carbonatites have consistently elevated REE contents. Wall (2004) describes inclusions of a burbankite-like phase in the ferroan dolomites of the pegmatoid carbonatite and relates the appearance of monazite to post magmatic processes. Mineralogical studies of REE enriched samples of the pegmatoid confirmed the presence of bastnaesite and daqingshanite $\left[(\mathrm{Ce})(\mathrm{Sr}, \mathrm{Ca}, \mathrm{Ba})_{3}(\mathrm{REE})\left(\mathrm{PO}_{4}\right)\left(\mathrm{CO}_{3}\right)_{3^{\prime \prime}}(\mathrm{OH}, \mathrm{F})_{\mathrm{x}}\right]$, a phase previously described from Nkombwa by Appleton et al. (1992). Apatite is an abundant primary cumulus mineral in the dolomitic carbonatites. Hydrothermal remobilisation of apatite within the pegmatoidal carbonatites has generated high phosphate concentrations hosted in secondary apatite and isokite $\left(\mathrm{CaMgPO}_{4} \mathrm{~F}\right)$. Isokite was first identified at Nkombwa Hill (Deans and McConnell, 1955) and is named after Isoka, the closest major village to Nkombwa.

REE mineralisation is well developed in the silicified rocks as well, highest grades being found where relict pegmatoidal textures are identified in the silicified carbonatite. Mobilisation of REE and phosphate from the primary carbonatite minerals during silicification was re-precipitated as a low-thorium, distinctly green monazite-(Ce) (Wall, 1996); along with minor bastnaesite and traces of cerianite.

An extensive surface outcrop sampling programme conducted between 2010 and 2012 identified several areas of elevated REE which were covered by close-spaced $(<10 \mathrm{~m})$ focussed sampling traverses. Kilogram-scale outcrop rock chip samples frequently returned grades of over $10 \%$ with the highest individual sample values being $23.6 \%$
TREO from the pegmatoidal carbonatite and 22.3\% TREO in the silicified unit. Phosphate concentrations are also elevated in the pegmatoidal carbonatite- the most enriched sample contained $33.3 \%$ $\mathrm{P}_{2} \mathrm{O}_{5}$ with just over $30 \%$ of the over 1,600 exploration samples collected having $>5 \%$ phosphate.

No recent drilling has been done and no resource has yet been defined on Nkombwa.

\section{Wigu Hill (Tanzania)}

\section{Location and Ownership}

Wigu Hill is a $719 \mathrm{~m}$ high mountain in the Morogoro District of Tanzania, approximately $250 \mathrm{~km}$ west of Dar es Salaam and about $10 \mathrm{~km}$ north of Kisaki village (Figure 1). The developer of the project is Montero Mining and Exploration (listed on TSX [TSX.V : MON]; http://www.monteromining.com).

\section{Geology}

Little published information is available on the geology of Wigu Hill (Woolley, 2001); the main source of geological information in the public domain can be found in Eggleston and Sides (2011), the technical report containing the first resource estimate for the project. Subsequent to this report, a substantial amount of mapping was carried out by company geologists - Montero management provided the authors an in-house report summarising these results prepared by Mr Paul Karpeta (Karpeta et al., 2012): the following review draws heavily on this report.

The Wigu Hill Complex is located on the northern margin of an

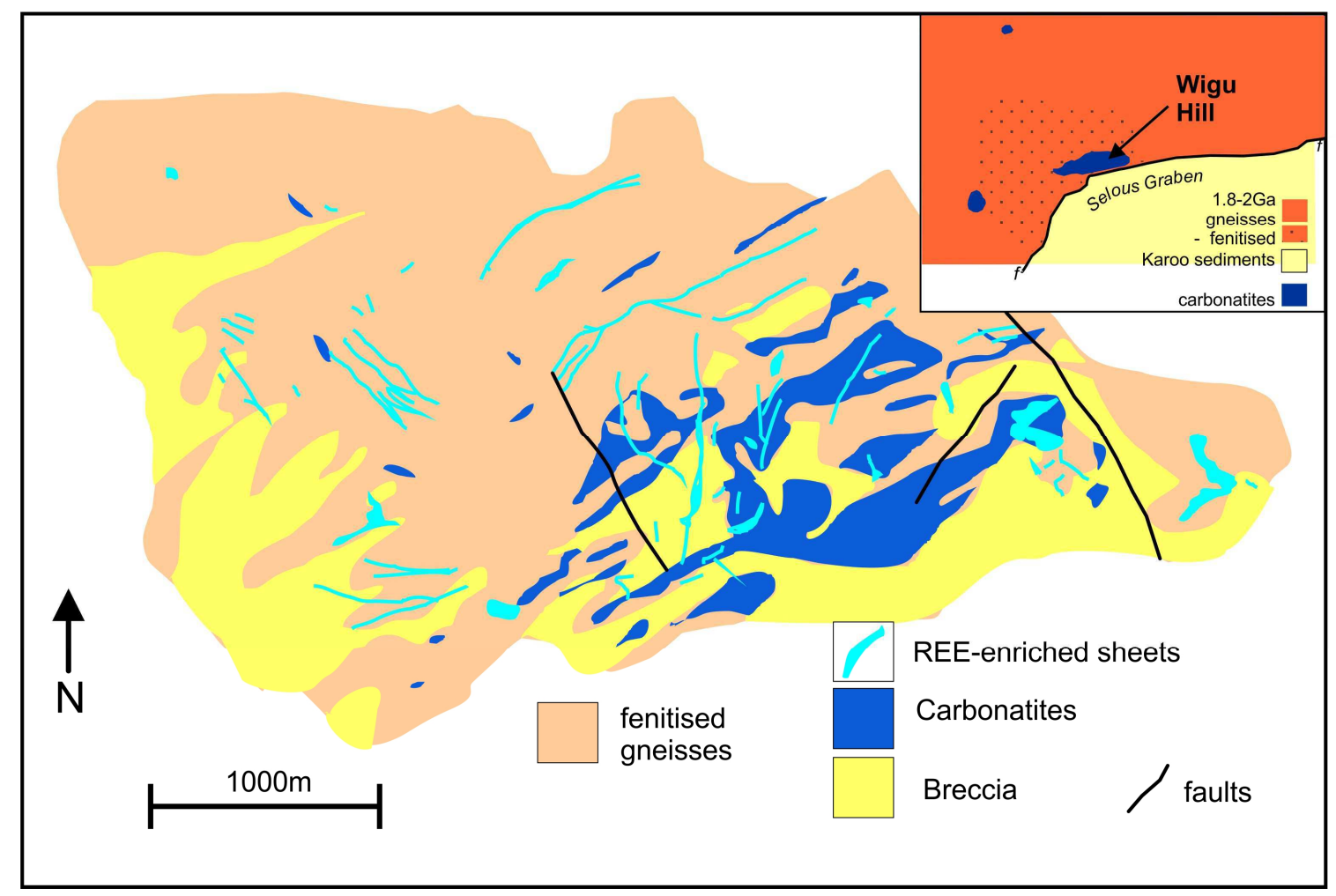

Figure 7: Geological map of Wigu Hill simplified from the outcrop map in Karpeta et al. (2012). Areas of superficial soil cover are not shown and the areas of sinter deposited by late-stage hot spring activity have been removed for clarity. The inset shows the setting of the Wigu Hill carbonatite on the flanks of the Selous Graben. 
ENE-WSW trending, Karoo-aged, graben that cuts 1.8-2.0 Ga Usagaran gneisses: the northern boundary fault defines the southern edge of the Complex. The graben is locally filled with Permo-Triassic Karoo sedimentary rocks.

Wigu comprises a series of sheeted intrusions of carbonatite and carbonatite breccia into basement gneisses over an area of over $5,000 \mathrm{~m}$ (east-west) by $1,500 \mathrm{~m}$. Carbonation of the gneisses is observed in places close to the intrusive contacts. Fenitisation of the gneisses involved the growth of aegirine and alkali feldspar in the gneisses, often accompanied by hematite. Signs of fenitisation are recognised $15 \mathrm{~km}$ from carbonatite outcrops. Foliations in the gneisses define a domal structure over the area of carbonatite intrusion.

\section{Carbonatites}

Two compositional varieties of carbonatite are recognised: medium-grained dolomitic carbonatites and coarse-grained calcite carbonatites; both of which may be locally brecciated. Magnesian carbonatites are composed of interlocking anhedral crystals of ferroan dolomite: while generally equigranular and massive, banding and foliation is often developed in these carbonatites and is sometimes flow-folded. Fresh varieties are white, becoming light brown as weathering causes oxidation of the $\mathrm{FeCO}_{3}$ component in the ferroan dolomite. Coarse calcitic carbonatites also weather brown suggesting the presence of some iron-rich components.

\section{Breccias}

Breccias range from monomictic types having mostly gneiss clasts, to polymictic types containing clasts of both gneiss and carbonatite. Breccia plugs are concentrically zoned with the degree of rounding of clasts increasing away from the margins as the relative volume of matrix increases. The most matrix-rich breccias are encountered in late dykes and plugs. A range of matrix compositions are found including silica, carbonate and rare earth bearing minerals: carbonate or REE matrices characterise the central area of the Hill whereas breccias in the eastern and western areas commonly have siliceous matrices.

\section{Mineralisation}

REE mineralised sheets occur in two textural forms: a "pegmatoidal" variety, and a finer-grained, streaky to foliated variety formed of aggregates of fine-grained, anhedral REE minerals set in a granular matrix of ferroan dolomite. Pegmatoidal types are composed of large ( $20 \mathrm{~cm}$ long) euhedral hexagonal crystals, either clustered in radiating rosette or "cockade" textures in the central parts of sheets (Figure 8) or radial to sub-parallel crystal growth orthogonal to the sheet margins. Zoning reflecting repeated periods of crystal growth is common. The large euhedral crystals are relics of primary burbankite which were pseudomorphed by aggregates of silica, baryte and mixed REE carbonate phases.

Mineralised sheets are aligned along three predominant strike directions: those oriented N-S or NNW-SSE tend to have steep dips and contain fine-grained, foliated style mineralisation; ENE-WSW oriented sheets have variable dips with pegmatoidal mineralisation developed in the steep portions and foliated mineralisation in shallower dipping sections. Sheet thicknesses can be up to $5 \mathrm{~m}$ - the more steeply inclined sheets usually being thicker. REE grades attain extreme values

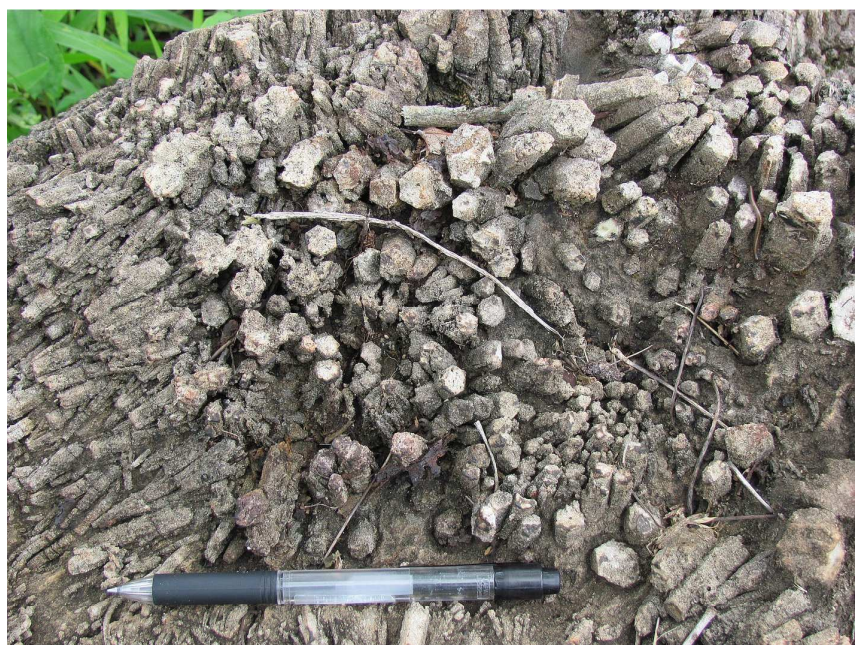

Figure 8: Radial clusters ("cockade" texture) of large relict euhedral burbankite crystals in the centre parts of a REE mineralised ferroan dolomite carbonatite sheet. Wigu Hill.

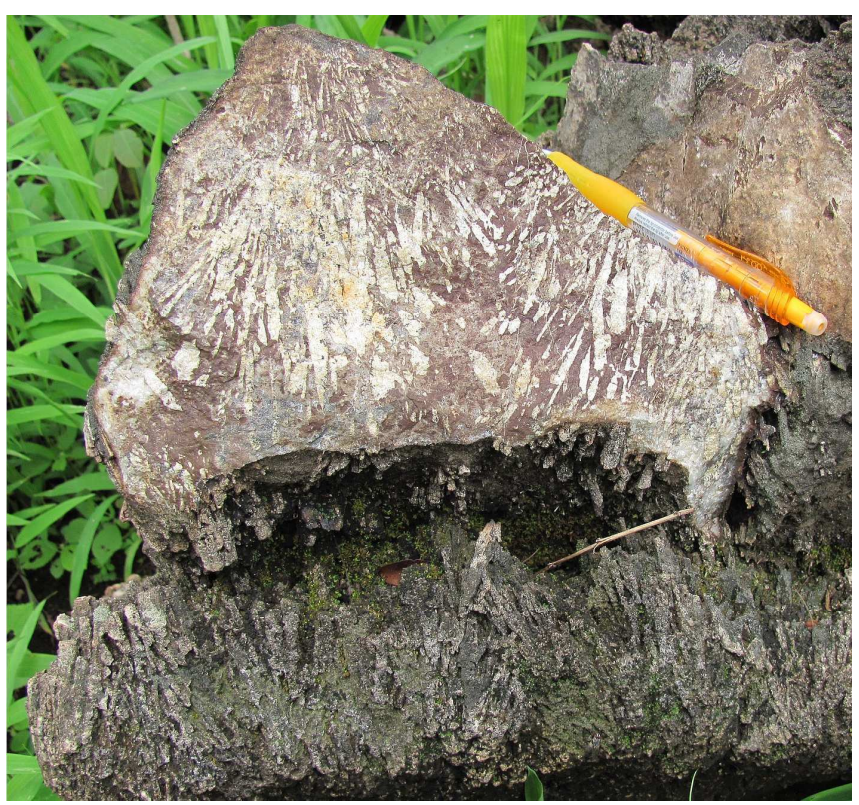

Figure 9: Wigu Hill:Large pseudomorphed burbankite megacrysts in altered iron-rich dolomite carbonatite.

in these sheets: the highest assay value obtained on kilogram-scale outcrop exploration grab samples is $26.2 \%$ TREO.

\section{Resource}

Mapping and surface sampling identified 10 target areas of REE mineralisation: resources have been reported for two of these - the "Twiga" and "Tembo" Zones (Eggleston and Sides, 2011). Additional drilling was subsequently completed over the Twiga Zone and a revised resource statement issued (Montero, 2013) reporting an inferred resource of 1.93 million tonnes at $2.69 \%$ TREO for 51,917 tonnes of contained REO. A resource was also estimated for an identified high grade, near-surface portion of the Twiga Zone mineralisation using a cut-off of 3\% TREO at an inferred level of confidence of 0.47 million tonnes at $5.26 \%$ TREO for 24,722 tonnes of contained REO. These resources represent a small fraction of the 
mineralised area on Wigu Hill - only 2 of 10 identified targets - leaving a substantial portion of the REE mineralisation as yet unexplored.

Details of the resource estimates are provided in Table 4.

\section{Lofdal (Namibia)}

\section{Location and Ownership}

The Lofdal REE project is situated in the Kunene Region of north-west Namibia, approximately $26 \mathrm{~km}$ west of the town of Khorixas and is covered by an Exclusive Prospecting License of 57,000 hectares held by the developer, Namibia Rare Earths Inc (TSX.NRE; www.namibiarareearths.com) (Figure 1).

\section{Geology}

Lofdal is underlain by units of the $\sim 2$ Ga Huab Metamorphic Complex which were intruded by the Lofdal alkaline-carbonatite Complex at around $750 \mathrm{Ma}$. The Lofdal Complex is composed of intrusions of nepheline syenite that were cut by two plug-like bodies of carbonatite-named the Main and Emanya intrusions- and an extensive swarm of phonolitic and carbonatitic dykes covering a surface area of around $200 \mathrm{~km}^{2}$ (Figure 11). Xenotime overgrowths on zircon from carbonatite dykes yielded a date of $765 \pm 16 \mathrm{Ma}$ (U-Pb LA-ICP-MS; Wall et al., 2008) that is equivalent to published dates for the Lofdal and Oas syenites (Hawkesworth et al., 1983; Hoffman et al., 1996; Jung et al., 2007).

The nepheline syenites are medium- to coarse-grained and locally porphyritic. In the Main carbonatite centre, nepheline syenite forms a carapace over the intrusive carbonatite. Breccias are associated with all the syenite bodies at Lofdal and contain coarse, angular clasts of country rock and syenite - relative proportions varying markedly between occurrences. The breccias contain no carbonatite clasts and are cut by dykes of both carbonatite and phonolite indicating that the breccia formed prior to intrusion of carbonatite. Calcite carbonatites predominate in both of the plugs, the Emanya intrusion carbonatites being finer-grained. Carbonatite in the Main intrusion contains accessory aegirine, apatite and magnetite with trace amounts of feldspar, sulphides and pyrochlore; iron oxides are abundant in the Emanya body imparting a reddish-brown colouration in outcrop.

Older reports on the Lofdal Complex describe the associated dyke swarm as being composed largely of carbonatite and phonolitic dykes but more detailed recent studies undertaken as part of the exploration effort have shown that a significant number represent carbonate-rich hydrothermal vein systems (Dodd et al., 2014). As such, these carbonate dykes should not be termed carbonatites (carbonatite being a magmatic rock: Le Maitre et al., 2002).

Phonolite dykes are closely associated with the "carbonate dykes" through the swarm: generally fine-grained to moderately porphyritic, they may locally develop trachytic textures and they are geochemically similar to the Lofdal nepheline syenite bodies.

\section{Mineralisation}

As a REE deposit, Lofdal's key characteristic is the extreme enrichment in the HREE elements relative to the LREE.

Lofdal's two carbonatite plugs have REE distributions considered as typical for magmatic carbonatites: enrichment in the LREE relative to HREE with no Eu anomaly. Total REE levels are significantly higher in the Emanya body but are sub-economic.

Based on a comprehensive geochemical survey of the Lofdal carbonate dykes, Swindon and Siegfried (2011) reported large variations in total REE and HREE:LREE contents amongst the dykes. They recognised two distinct types of REE mineralisation one dominated by the LREE with similar LREE/HREE to the Emanya carbonatite; the other showing increasing HREE/LREE with increase in total REE (see Figure 22b). These HREE enriched "dykes" represent carbonate-rich hydrothermal veins, which range in width from less than $10 \mathrm{~cm}$ to tens of metres. Alteration involves an early pervasive albitisation, followed by brittle fracturing and "infusion of carbonate minerals and micas" (Dodd et al., 2014, p81). This alteration appears to critically control the HREE mineralisation. Most HREE-mineralised zones lie along linear alteration trends that are interpreted to reflect fluid pathways focussed by basement-related structures and appear independent of the nature of the host lithologies. Significantly, the high HREE to total REE nature of the mineralisation persists to low overall TREO grades (Dodd et al.,2014).

HREE mineralisation has been proved over a lateral extent of over $15 \mathrm{~km}$ across the project property but a smaller target area termed "Area 4" by the developers (Figure 10) - was prioritised for development (Siegfried and Hall, 2013; Dodd et al.,2014). Situated to the south-east of the Main carbonatite intrusion, Area 4 represents a mineralised segment approximately $650 \mathrm{~m}$ long. Mineralisation is aligned along a major fault that extends for several kilometres on either side of Area 4: the orientation of the fault closely follows the fabric of the host gneisses, being ENE-trending and southwarddipping, and has a sinistral sense of movement (Figure 11).

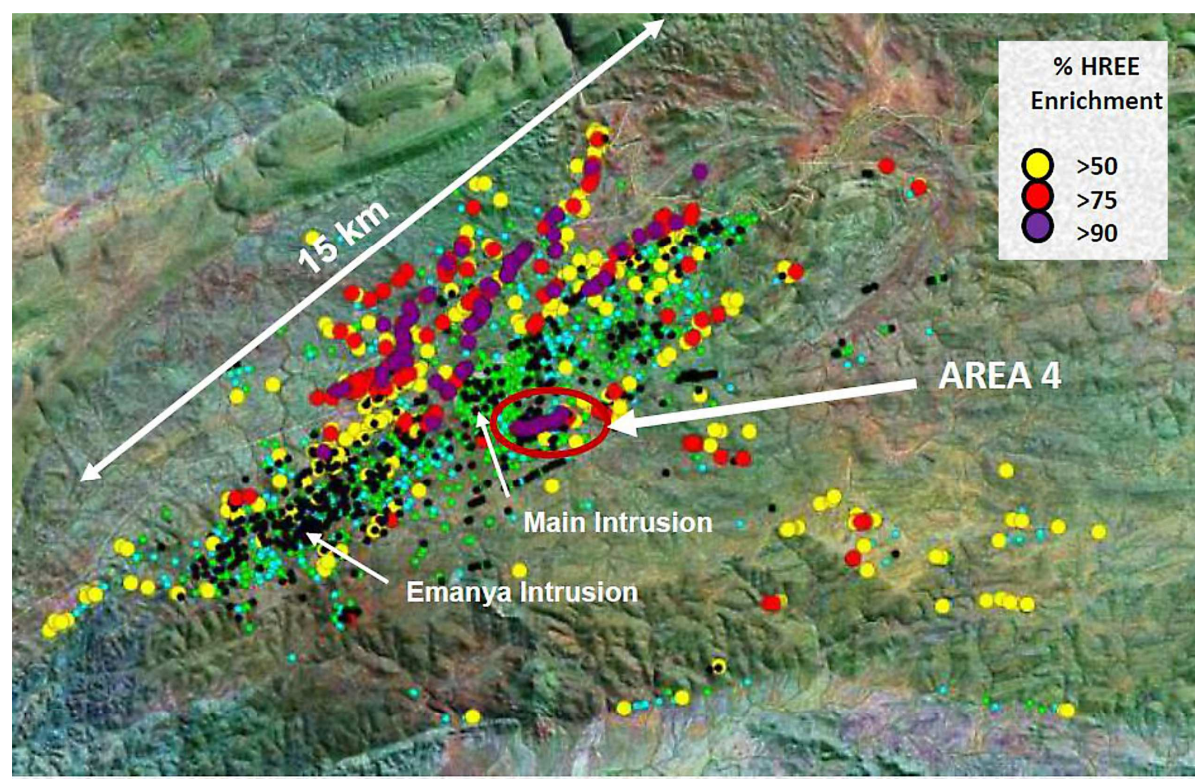

Figure 10: Map showing distribution of HREE enrichment across Lofdal license area and the locations of the two carbonatite intrusions and the "Area 4" resource area (diagram courtesy of Namibia Rare Earths, Inc). 


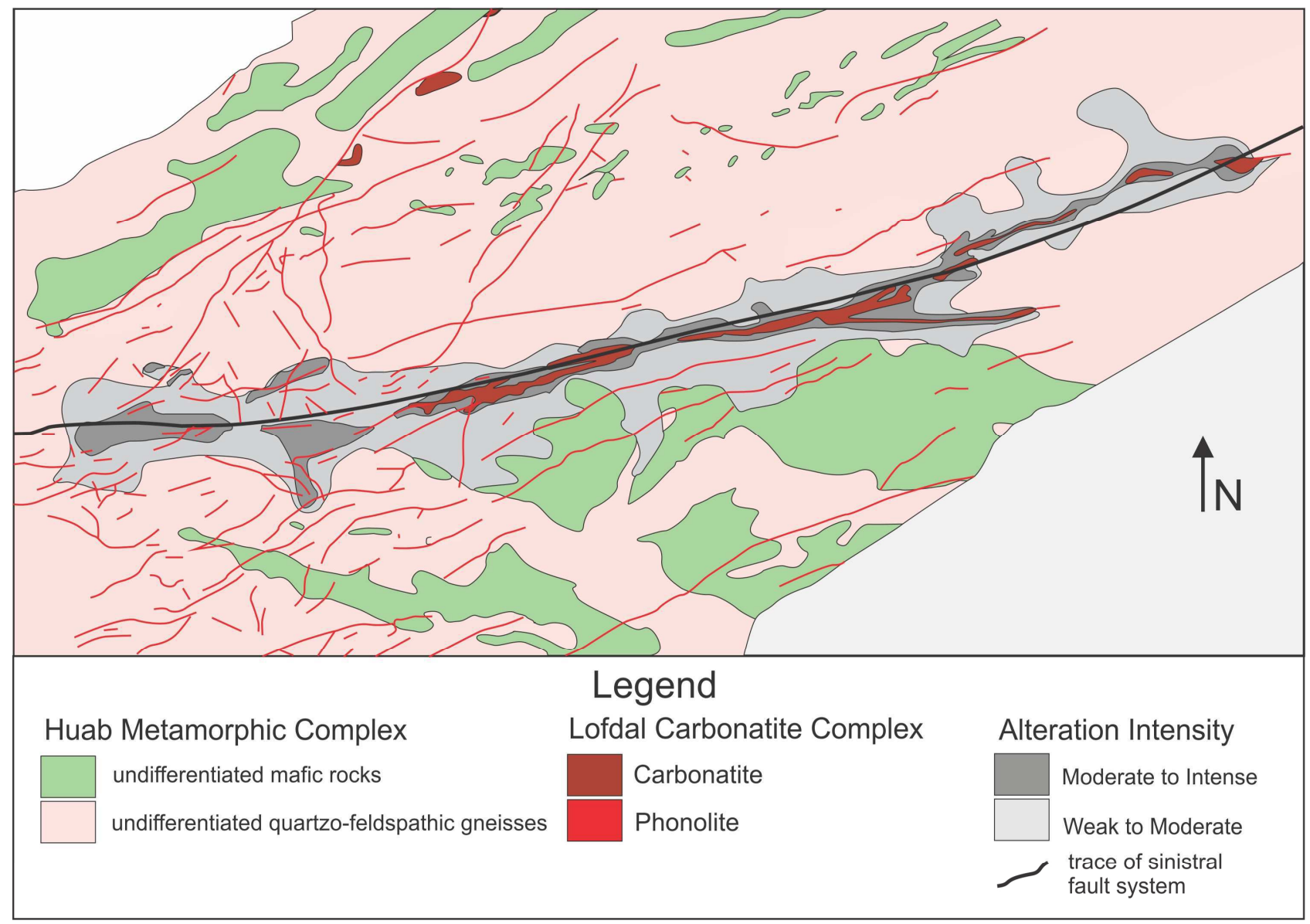

Figure 11: Geological map of the Lofdal Target 4 overlain with the zones of alteration intensity (after Siegfried and Hall, 2012).

Alteration is recognised at surface by bleaching and reddening related to linear sheared structural features marked by the development of biotite, phlogopite, chlorite and calcite, together with albite, dolomite and iron oxides. Multiple episodes of alteration are recognised with albitisation prevalent during the early stages and carbonation characterising later episodes. High-grade HREE mineralisation is manifested by veinlets, vein networks, red alteration patches and micro-breccia veins. Typically, where multiple generations of alteration are recognised, the REE enrichment is associated with the youngest event (Dodd et al., 2014).

HREE mineralisation is principally hosted in xenotime, which contains $90 \%$ of the HREE deportment (Loye et al., 2014), along with a diverse array of minor REE-bearing phases including aeschynite-(Y), bastnaesite, parisite, synchisite-(Ce), synchisite-(Y) and monazite-(Ce). Xenotime occurs in several parageneses that reflect the transition from late magmatic through to evolve hydrothermal conditions.

The HREE mineralisation at Lofdal is argued to post-date the carbonatite-related fenitisation as well as the brecciation caused by carbo-hydrothermal fluids (Loye et al., 2014).

\section{Resource}

A resource estimate for Area 4 was reported in July 2013 (Siegfried and Hall, 2013) and formed the basis of a Preliminary Economic Assessment study completed in October 2014 (Dodd et al., 2014), which identified $2.88 \mathrm{Mt}$ of indicated resource with a grade of
$0.32 \%$ TREO for $9.22 \mathrm{kt}$ of contained REO, plus a further $8.86 \mathrm{kt}$ of REO at inferred level. Details are provided in Table 4.

\section{Ngualla Hill deposit (Tanzania)}

\section{Location and Ownership}

The Ngualla Hill REE deposit is located near Mbeya in southwest Tanzania and is being developed by Peak Resources (ASX:PEK; www.peakresources.com.au) (Figure 1).

\section{Geology}

The project is centred on the Proterozoic Ngualla Hill carbonatite complex which lies within the western limb of the East Africa Rift System. The age of the intrusive complex is uncertain but Cahen and Snelling (1966) published a K-Ar date of $1040 \pm 40$ Ma for an igneous biotite from Ngualla.

The carbonatite complex is circular in outline with a diameter of approximately $4 \mathrm{~km}$ by $3.5 \mathrm{~km}$ and is interpreted to be pipe-like in form (Figure 12). Country rocks are Proterozoic gneisses, quartzites and rhyodacitic volcanics. Fenitisation of the country rocks caused the metasomatic growth of alkali feldspar, biotite and riebeckite and generated a kilometre-wide alteration zone that is relatively resistant to erosion and forms a ring of hills surrounding the carbonatite intrusion. Woolley (2001) describes (and depicts on his map) a substantial zone of brecciated fenites along the outer contact of the carbonatite. 


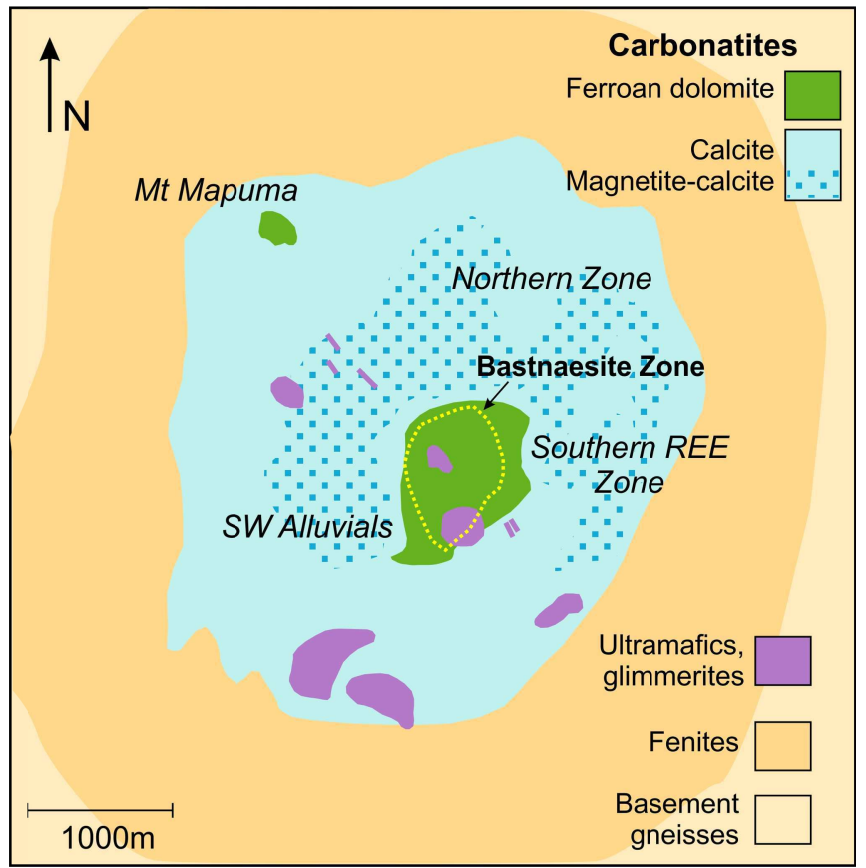

Figure 12: Geological map of the Ngualla Hill Carbonatite (modified from Peak Resources, 2014). The magnetite calcite carbonatite area was outlined by Peak Resources using magnetic data. The Bastnaesite Zone is the principle REE resource area.

The carbonatite plug is composed of an annular body of calcite carbonatite that was intruded by a central plug of dolomitic carbonatite. The early calcite carbonatite contains variable amounts of phlogopite, richteritic amphibole, magnetite and apatite with minor to trace amounts of ilmenite, sulphides (mainly pyrrhotite) and monazite. The dolomite carbonatite is predominantly composed of ferroan dolomite (as such, references to this body as "ferrocarbonatite" is misleading: e.g. Witt et al., 2013; Peak Resources, May 2014) and contains miarolitic cavities in which quartz, calcite, baryte, fluorite and REE fluorocarbonates (synchisite, bastnaesite) are found. The abundance of these minerals appears to increase inwards from the margins of the dolomite carbonatite plug. Ovoid to irregular bodies of hematite-baryte concentrations up to several metres in size occur within the central part of the dolomite carbonatite plug. Sulphides, where present, are minor constituents with pyrite the dominant phase.

In addition to the carbonatites, olivine-bearing ultramafic and mica-rich glimmerites have been identified within the complex: they are generally poorly exposed but are inferred from strong magnetic anomalies (Witt et al., 2013).

\section{Mineralisation}

REE concentrations in the calcite carbonatite are generally less than $0.25 \%$ TREO and are held in monazite. Magnesian carbonatites have higher REE grades which are contributed by the fluoro carbonate phases synchisite and bastnaesite. In unweathered ferroan dolomite carbonatite the TREO grades increase inwards from about $0.5 \%$ or less near the periphery to 1 to $2 \%$ in the centre; a trend ascribed to in situ fractional crystallization (Witt et al., 2014). Higher primary grades (3-5\% TREO) are sporadically found in close proximity to ultramafic units; however, such enrichment is not consistent.
The primary REE levels in the Ngualla carbonatites were enhanced, in places to ore grade levels, through the action of alteration and weathering.

Dolomite carbonatite weathers through oxidation of the $\mathrm{FeCO}_{3}$ component in ferroan dolomite and dissolution of the $\mathrm{CaMg}\left(\mathrm{CO}_{3}\right)_{2}$ component, a process facilitated by the presence of miarolitic cavities in, and associated higher porosity of, the dolomite carbonatite. Dissolution and removal of carbonate caused a significant mass reduction and produced a porous, goethite-rich regolith unit with a very low S.G. (1.84). Quartz, baryte and rare earth minerals are unaffected by weathering and are residually enriched in the goethiterich regolith. Further oxidation of goethite to hematite caused a further volume reduction $(\sim 27 \%)$ and generated a compact, higher density rock (S.G. 2.28) with little additional upgrading of REE concentrations (Witt et al., 2013). The contact between regolith and underlying fresh carbonatite can be remarkably sharp - this is illustrated in Figure 13.

The principle REE resource area at Ngualla - The Bastnaesite Zone - is centred on Mount Ngualla (Figure 12 and Figure 14). Here REE mineralisation is hosted by an in situ iron oxide and baryte-rich weathering shell overlying fresh dolomite carbonatite. Weathering depths are highly variable but grades in excess of 3\% TREO are common within the iron oxide-baryte-rich material over thicknesses of up to 140 metres. Studies of the iron oxide-rich material show that REE occur in bastnaesite and synchisite indicating that weathering has not greatly modified the primary REE mineralogy (Witt et al., 2014).

Enrichments in the REE content of the regolith relative to the primary carbonatite range up to $300 \%$.

Minor additional REE resources are hosted in colluvium developed in two alluvial channels. One is hosted by colluvium deposited in an erosional channel incised into the outer margin of the dolomite carbonatite: in contrast to the regolith, rare earths in these

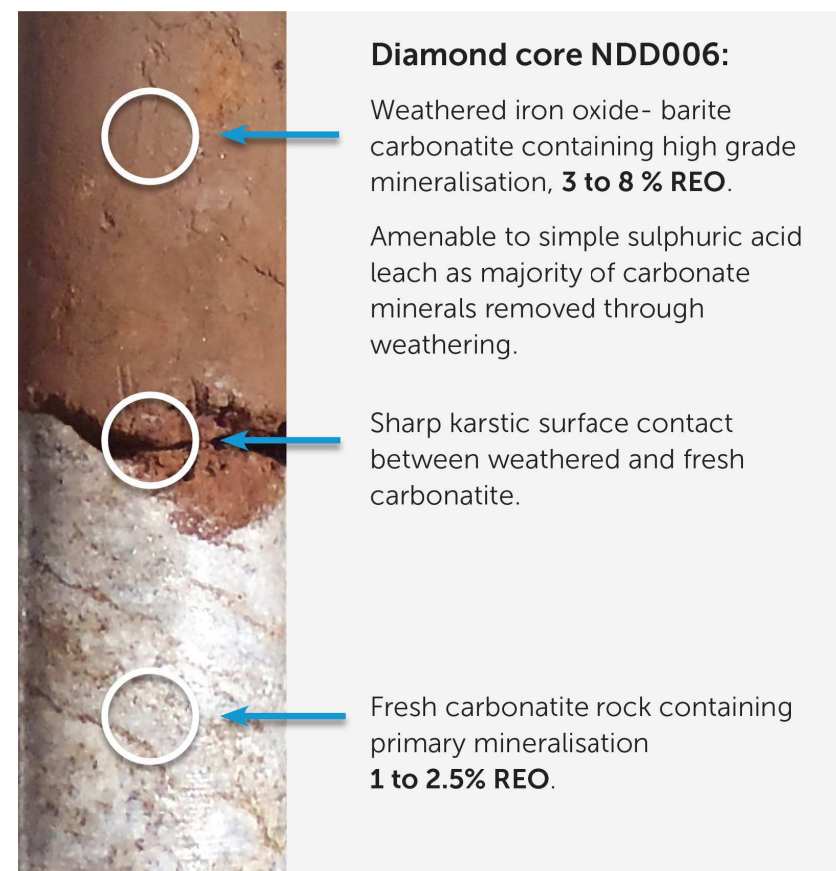

Figure 13: Section of borehole core from Ngualla Hill prospect showing the extremely abrupt contact between fresh carbonatite and extensively leached and weathered material (diagram courtesy of Peak Resources, 2014). 


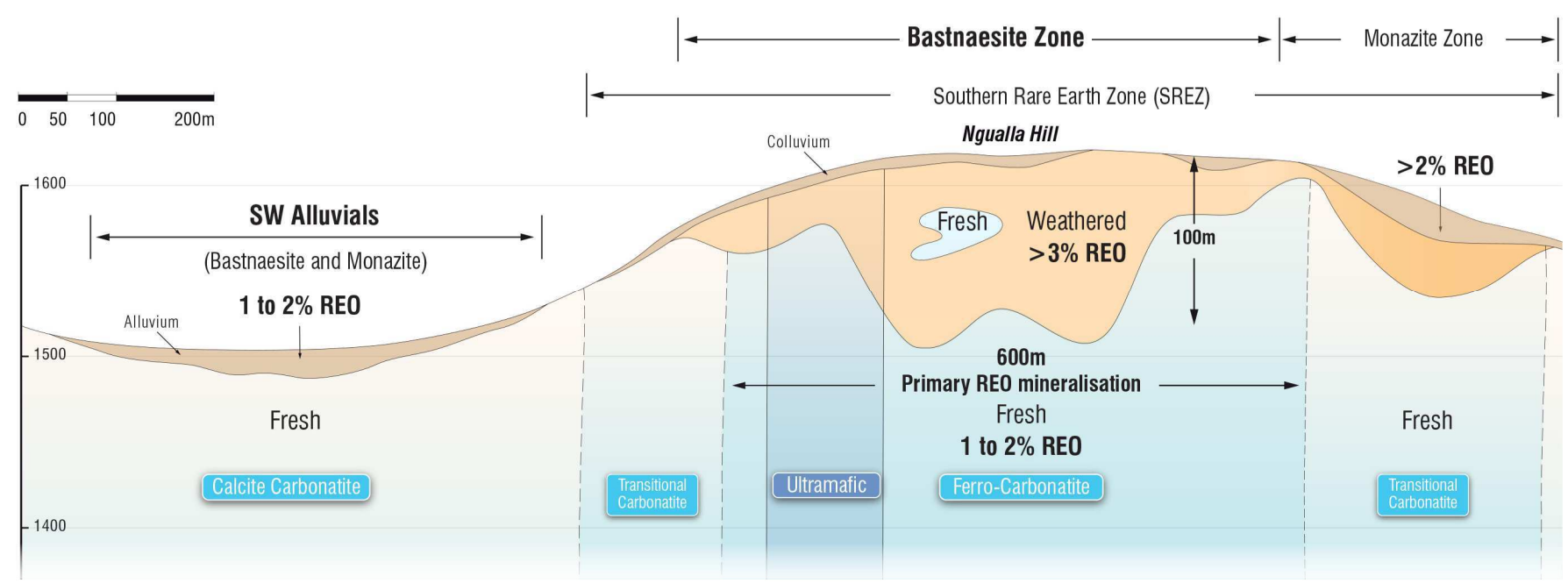

Figure 14: Section through Ngualla Hill showing the relationships between the different mineralised zones (diagram courtesy of Peak Resources, 2014).

colluvium channels are hosted in monazite, lesser cerianite, and bastnaesite (Witt et al., 2013).

\section{Resource}

In the REE resource for Ngualla Hill published in April 2013 (Peak Resources, 2013), JORC compliant resources were calculated at cut-off grades of $1 \%$ and $3 \%$ TREO and yielded resource grades of $2.26 \%$ and $4.19 \%$ TREO respectively. While the high grade option represents only $22 \%$ of the total resource, it is sufficient for a project life of more than 50 years at conventional processing rates. As a consequence, the Preliminary Feasibility Study (Peak Resources, 2014a) focussed on the high grade core- the central Bastnaesite Zone Weathered Mineralisation, where ore reserves are 20.7 million tonnes at $4.54 \%$ TREO for 941,000 tonnes of contained REO (Peak
Resources, 2014b). Resource and reserve estimate details are provided in Table 4.

\section{Mrima Hill (Kenya)}

\section{Location and Ownership}

Mrima Hill is one of a cluster of carbonatite and alkaline intrusions located $60 \mathrm{~km}$ to the south-west of Mombasa and $10 \mathrm{~km}$ from the coast of southern Kenya (Figure 1). The Mrima Hill Project is covered by a Special Mining Lease held by Cortec Mining Kenya Limited (CMK); Pacific Wildcat Resources Corporation (TSX.V:PAW; www.pacificwildcat.com), the operators developing the project, own $70 \%$ of CMK. The Ministry of Mining of Kenya revoked all Prospecting, Exploration and Mining licenses issued between

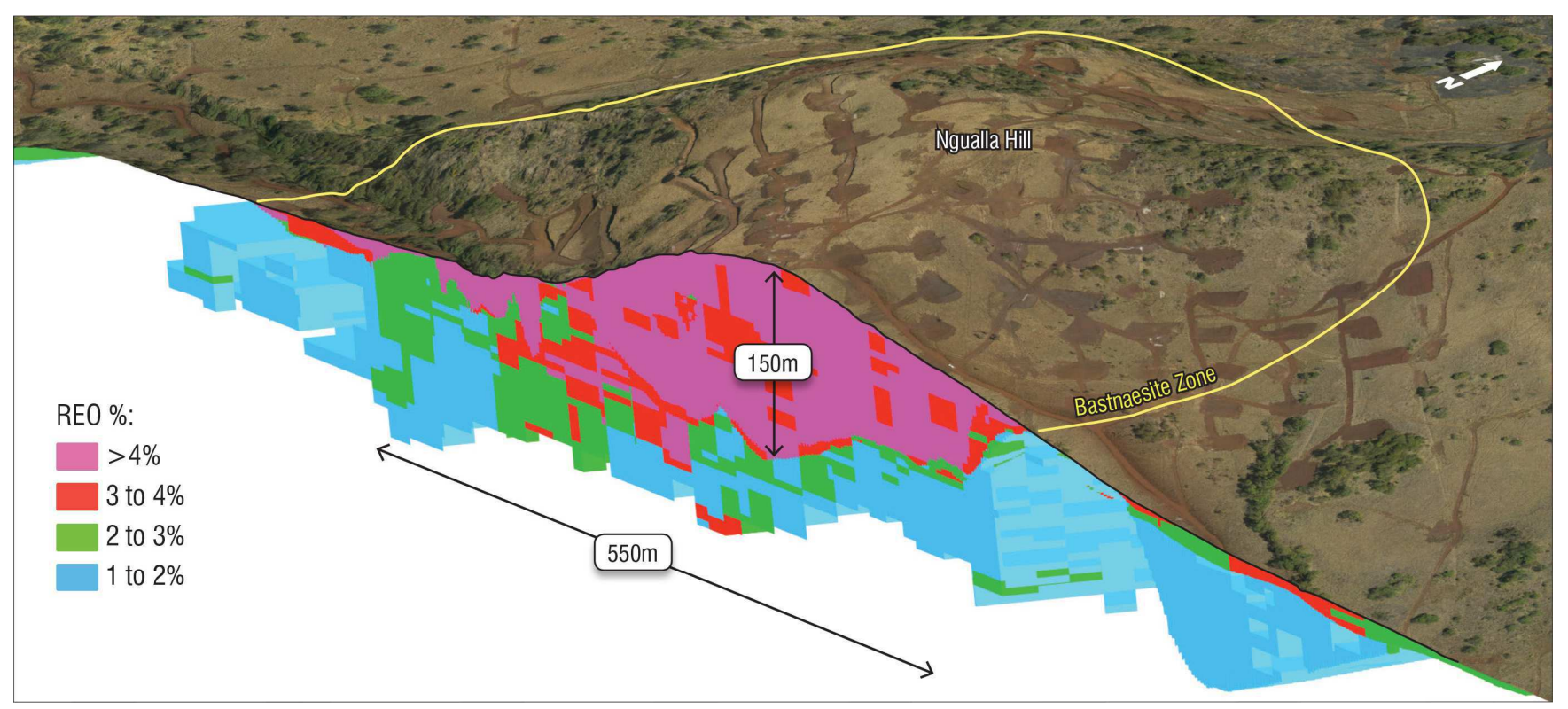

Figure 15: 3D perspective view of distribution of REO values in a section through the resource model for Ngualla Hill. The contrast between fresh carbonatite and Weathered Bastnaesite Zone Mineralisation is clearly revealed by the \%TREO values (diagram courtesy of Peak Resources, 2014). 
$14^{\text {th }}$ January and $15^{\text {th }}$ May 2013, including Cortec's license over Mrima Hill. Cortec's appeal of this decision was not upheld by the High Court (20 March 2015) and the current status of the license is not clear.

\section{Geology}

Mrima Hill and associated intrusions are Cretaceous in age and were emplaced into a fault-bounded basin of Jurassic-age Karoo sediments.

Mrima Hill consists of carbonatite, agglomerate and fenitised sediments overlain by weathered materials (Northrup et al., 2011; Pollard and Mapleson, 2013). Outcrop is poor with much of the hill draped in laterite which attains thicknesses of over $100 \mathrm{~m}$ in the central parts. Fenitised sandstone and siltstone occur at the south-western and south-eastern margins of the Mrima Hill intrusion; fenitisation of the sandstones has generated orthoclase and aegirine.

The carbonatite is predominantly a coarse- to medium-grained calcite carbonatite, micaceous in places, with lesser amounts of dolomite carbonatite. Calcite carbonatites crop out on the south-east to north-west side of the hill, while outcrops of dolomitic carbonatite are found on the western side of the hill. Accessory phases in the carbonatites include amphibole, biotite, pyrite, pyrochlore and fluorite. Angular to rounded fragments of biotite-rich calcitedolomite carbonatite have been reported from within the calcite carbonatite.

Agglomerate outcrops are confined to the south-western slopes of the hill and are composed of fragments of sedimentary rocks, crystals of biotite, hornblende, aegirine-augite and microcline, set in a calcite-rich matrix.

\section{REE-Niobium mineralisation}

Economic grades of REE and niobium mineralisation are developed in the laterite capping produced by weathering of the igneous components of Mrima Hill under the tropical climatic conditions experienced in southern coastal Kenya. Weathering products of the carbonatite rocks include silicified rock, ironmanganese rock, saprolite and lateritic soils enriched in phosphates, rare earth oxides, niobium and barium; and depleted in calcium, alkalis and magnesium.

\section{Resource}

In September 2013, Pacific Wildcat Resources Corporation declared an indicated REE resource of 48.7 million tonnes at $4.40 \%$ TREO for 2.15 million tonnes of contained REO; with a further 4 million tonnes of contained REO in the inferred category (Pollard and Mapleson, 2013). Full details of the defined REO resource at Mrima are provided in Table 4.

Development of the Mrima Hill deposit has been suspended pending the resolution of the dispute regarding the company's license.

\section{Zandkopsdrift REE deposit (South Africa)}

\section{Location and Ownership}

The Zandkopsdrift Project lies close to the Atlantic coast in the south of the Northern Cape Province of South Africa (Figure 1).

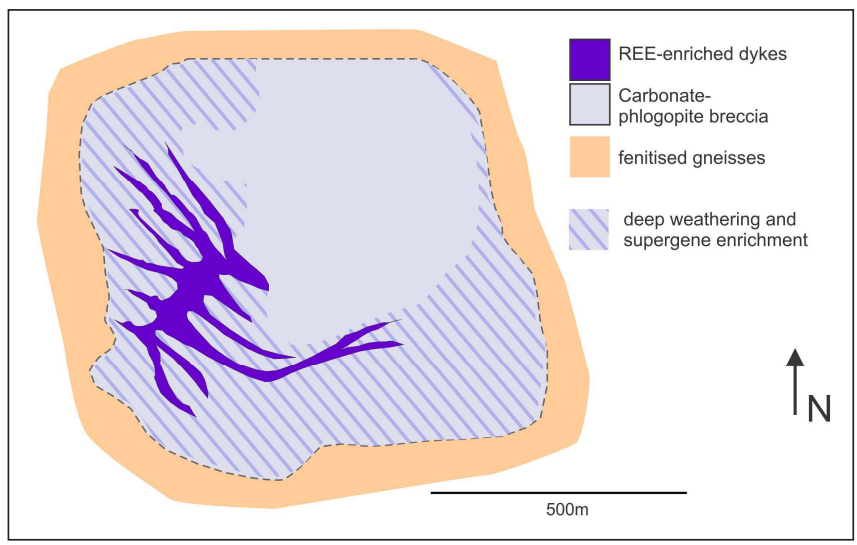

Figure 16: Geological map of the Zandkopsdrift Complex (after Harperet al., 2014).

Development of the project is managed by Frontier Rare Earths Ltd. (TSX-listed; http://www.frontierrareearths.com); ownership details are documented in Harper et al. (2011).

\section{Geology}

The Zandkopsdrift carbonatite is located within the bounds of the Cretaceous-aged Koegel Fontein Complex: a suite of alkali granites, syenites and carbonatites that intruded the gneisses of the western part of the Mesoproterozoic Namaqua-Natal metamorphic belt during the $130 \mathrm{Ma}$ rifting phase that preceded the opening of the southern Atlantic Ocean. Zandkopsdrift has recently been dated at 55.9 $\pm 4.3 \mathrm{Ma}$ (reported in Harper et al., 2014) and so significantly post-dates the Koegel Fontein Complex and is related to the regionally extensive group of Tertiary Olivine Melilite and Kimberlite pipes and diatremes described by Moore and Verwoerd (1985).

Zandkopsdrift is a $1,300 \mathrm{~m}$ by $900 \mathrm{~m}$ ovoid-shaped intrusion described as a "carbonatitic breccia pipe" (Harper et al., 2014) that is covered by Quaternary sands and unconsolidated sediments. Several smaller satellite intrusives, plugs and dykelets, have been identified around the main central plug.

The initial phase of intrusion was accompanied by brecciation and fenitisation of the host gneisses- brecciation being discernible at distances of a kilometre from the main intrusive. The main plug is built of sub-vertical dykes of phlogopite-carbonate breccias

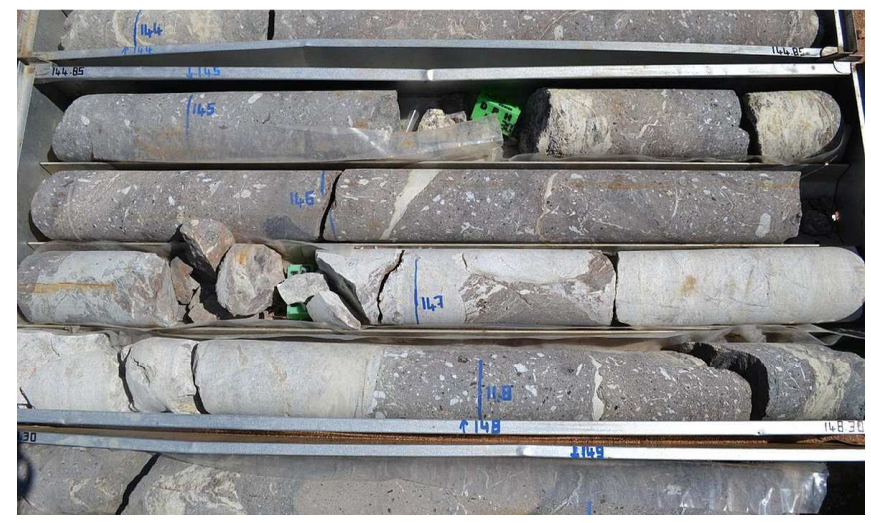

Figure 17: Core showing late REE-enriched carbonatite sheet (light coloured) cutting carbonate-phlogopite breccia (darker, grey) in the Zandkopsdrift Complex (Hayward, 2013). 
("carbonatitic phlogopite breccia" or "CPB") which were intruded by sub-vertical to vertical REE-enriched dykes, dykelets and vein swarms. At least two facies of breccia are recognised on the basis of clast size: while relationships between the facies are complex, intrusion of the finer facies generally post-dates emplacement of the coarser variety. The late-stage, REE-enriched dykes are mostly encountered in the south-western quadrant of the complex. Intrusion of these dykes resulted in brecciation of the host $\mathrm{CPB}$, with feather-fractures developed in the breccias close to the intrusive contacts. Sequential injections of the later dykes are reported to have caused "devolatisation and alteration" of the earlier breccias (Harper et al., 2014). The final intrusive phase recognised at Zandkopsdrift is the emplacement of rare dykes and plugs of "grey-coloured magnetic" rock.

Little petrographic detail on the different components of the complex is supplied in the available technical reports but photographs of fresh phlogopite-carbonate breccia suggest that carbonate mineral contents are low $(<20 \%)$ and consist of angular clasts: as such, the intrusion is clearly not a true carbonatite. Harper et al. (2011) describe the rock as containing " $0.5 \mathrm{~mm}$ to $10 \mathrm{~mm}$ scattered grains of calcite, biotite, magnetite and country rock, with disseminated pyrite". Results of a scanning electron microscope study of the fresh carbonatite phlogopite breccia and REE-enriched dyke material are reported in Harper et al. (2014), where it is somewhat confusingly claimed that the CPB sample(s) contained 88 weight percent "carbonate" whereas the dyke(s) had 59.6 weight percent "carbonatite minerals".

\section{Mineralisation}

Despite the lack of true carbonatite amongst the various components of the complex described in the technical reports, the complex as a whole, and the late REE-enriched dykes, are consistently interpreted as "carbonatitic" (Venter et al., 2010; Harper et al., 2012, 2014).

Primary REE enrichment is interpreted to be magmatic, the progressive concentration of incompatible REEs as the various intrusive "carbonatitic" phases evolved and crystallised; this enrichment being enhanced by late stage hydrothermal remobilisation and enrichment of the REEs through the dyke assemblage. The primary, unaltered breccia/dyke assemblage at Zandkopsdrift has REE grades generally below or close to $1 \%$ TREO (the cut-off grade used for the original resource estimate: Venter et al., 2011).

The complex has undergone several stages of alteration (including late magmatic/hydrothermal) and weathering - the average depth of the weathering profile being $80 \mathrm{~m}$. Primary levels of REE are enriched in the weathered material through supergene processes discussed previously: replacement of primary phases by secondary iron and manganese oxides and hydroxides generates limonitic Fe-Mn saprolite or Fe-Mn "wad". Sulphides such as pyrite and pyrrhotite are noted in fresh diamond drillhole cores: acidic fluids generated from the alteration of such phases would have assisted in accelerating the breakdown of the primary carbonatite phases. Silicified and manganiferous varieties of laterite are encountered in the weathered profile (Venter et al., 2010; Harper et al., 2011).

Supergene REE enrichment is concentrated in the western and south-western portions of the complex. Two zones are distinguished based on broad lithological and grade characteristics: a higher grade Central Zone, where grades exceed 2.5\%TREO; and a lower grade Outer Zone where grades are typically 1 to $1.5 \%$ TREO. Enhanced
REE grades in the Central Zone are the result of a greater abundance of REE-enriched dykes relative to CPB in the protolith.

Available mineralogical studies show that the majority of the REE-bearing minerals consist of late-stage, supergene members of the monazite group; along with apatite-derived REE phosphate phases such as gorceixite $(\mathrm{Ba}, \mathrm{REE}) \mathrm{Al}_{3}\left(\mathrm{PO}_{4}\right)_{2}\left(\mathrm{OH}_{5} \cdot \mathrm{H}_{2} \mathrm{O}\right)$, goyazite $(\mathrm{Sr}, \mathrm{REE}) \mathrm{Al}_{3}\left(\mathrm{PO}_{4}\right)_{2}\left(\mathrm{OH}_{5} \cdot \mathrm{H}_{2} \mathrm{O}\right)$, crandallite $(\mathrm{Ca}, \mathrm{REE}) \mathrm{Al}_{3}\left(\mathrm{PO}_{4}\right)_{2}$ $\left(\mathrm{OH}_{5} \cdot \mathrm{H}_{2} \mathrm{O}\right)$ and cheralite (REE,Ca,Th) $(\mathrm{P}, \mathrm{Si}) \mathrm{O}_{4}$ (Harper et al., 2011, 2015).

\section{Resource}

A Pre-Feasibility Study was concluded on the Zandkopsdrift Project in late 2014 (Harper et al., 2014) which included a reassessment of the mineral resources and a statement of mineral reserves - these are detailed in Table 4.

Proven Reserves amount to $14.93 \mathrm{Mt}$ at a grade of $2.21 \% \mathrm{TREO}$ for 331,000 tonnes of contained REO, with an additional $458 \mathrm{kt}$ of contained REO as Probable Reserve.

\section{Xiluvo REE deposit (Mozambique)}

\section{Location and Ownership}

The Xiluvo REE Project lies within the Xiluvo carbonatite complex located in the Sofala Province of Mozambique some $110 \mathrm{~km}$ inland of the port of Beira (Figure 1). The project lies within a mining license held by Promac lda, who have operated a quarrying operation for building aggregate on parts of the carbonatite for several decades. The REE project was investigated through a joint venture arrangement operated initially by Southern Crown Resources (ASX) and subsequently, Galileo Resources plc (AIM): the joint venture option was not exercised and interest in the project reverted to Promac in 2012.

\section{Geology}

Monte Xiluvo is a conspicuous set of quasi-circular hills that rise $700 \mathrm{~m}$ above the surrounding plains underlain by Neoproterozoic metamorphic rocks. These hills form the outer parts of the Xiluvo complex and are composed of an agglomerate apron of coarse, clastsupported breccias, comprising angular clasts of country rock gneisses and schists set in a matrix of finely pulverized silicate material. Carbonate is absent from the outer portions of the agglomerate apron but becomes more common towards the centre; rare clasts of carbonatite are found in the innermost parts close to the carbonatite bodies.

The agglomerate is intruded by a composite plug of carbonatite. Calcite carbonatite forms the earliest intrusive phase and occupies an incomplete annular ring along the outer margin of the carbonatite plug. These early carbonatites generally comprise extremely coarse platy calcite crystals over $2 \mathrm{~cm}$ in length and commonly contain streaky and patchy concentrations of aegirine and scattered pyrochlore. They are intruded by a second phase of calcite carbonatite that is uniformly fine-grained and greyish in colour; narrow sheets of this second carbonatite phase are sometimes found intruding the agglomerate. The last recognised intrusive phase in the complex is a series of sheets, plugs and veinlets of iron-rich tuffisite material. In the larger plugs the tuffisite is a matrix-supported breccia where angular and 
sub-rounded clasts of earlier carbonatites and country rocks are enclosed in an orange to brown hematite-rich carbonate matrix. Tuffisite plugs are found intruding country rocks beyond the limits of the complex.

\section{REE mineralisation}

Geochemical sampling of the Xiluvo carbonatites showed moderate REE concentrations in the calcitic intrusives (typically $<0.8 \%$ TREO) with higher concentrations - up to $2 \%$ TREOsporadically developed in the tuffisitic phase.

The quasi-ring structure of the outer agglomerate ridges forms a blind drainage basin in the inner valley between the central carbonatite plug and the western ridge: unconsolidated elluvial and colluvial soils accumulated in this topographic bowl and are enriched in REO, phosphate and niobium. Reconnaissance pit sampling of the soils revealed REE concentration ranges of 1.8-3\% TREO with attractive concentrations of the heavy REE.

Mineralogically, the soils are essentially free of clays and comprise a mixture of iron oxides and hydroxides with smaller amounts of quartz and manganese oxides; the REE mineral is predominantly a low-Th variety of monazite.

\section{Resource}

The soil deposit was systematically drilled to bedrock at $50 \mathrm{~m}$ x $50 \mathrm{~m}$ spacing in July 2011 using a powered, sheathed augur technique, that returned undisturbed samples. A total of 220 holes were drilled from which the extent and depth of the soil deposit was determined to be far more limited than anticipated.

An Indicated category REE and $\mathrm{P}_{2} \mathrm{O}_{5}$ resource was estimated (according to the JORC specifications) on the basis of 220 boreholes (Southern Crown Resources release to the ASX: 10 November 2011). Details are provided in Table 4. As a consequence of the limited size of the resource and with no prospect of increasing this with additional exploration, the joint venture option was not exercised and the project was dropped.

\section{Glenover REE-Phosphate deposit (South Africa)}

\section{Location and Ownership}

The Glenover Complex is located in the Lephalale (Ellisras) district of north-western Limpopo Province in South Africa (Figure 1). The Exploration Right over the property is held by Glenover Pty Ltd. (www.glenover.com) who is developing the project through a joint venture arrangement with Galileo Resources plc (www.galileo resources.com).

\section{Geology}

Glenover is composed of an oval $3.5 \times 4.5 \mathrm{~km}$ sized plug-like intrusion of micaceous pyroxenite and carbonatite, emplaced into quartz-arenite sediments of the Waterberg Group. The age of the complex is poorly constrained but Verwoerd (1967) reported an imprecise monazite date of $1000 \pm 200 \mathrm{Ma}$; there is no compelling evidence to doubt that Glenover was emplaced at the same time as the other mid-Proterozoic, post-Waterberg alkaline and carbonatite complexes (as reviewed in Hanson et al., 2006).

Biotite-diopside pyroxenite makes up the major part (over $90 \%$ by volume) of the intrusion. Banding of mica- and pyroxene-rich layers, sometimes accompanied by massive magnetite, occurs in places. Apatite is a ubiquitous accessory phase, and in places can reach modal abundances of $15-20 \%$; Verwoerd (1986) describes the average phosphate content in the pyroxenite as $5 \% \mathrm{P}_{2} \mathrm{O}_{5}$. Phlogopite often occurs in place of biotite; alteration to vermiculite is common and several areas of vermiculite mineralisation have been defined within the pyroxenite.

The pyroxenite plug was intruded by carbonatites which most commonly occur as metre-scale, arcuate to annular sheets with an associated network of anastomosing thin carbonatite veins. A central concentration of carbonatite was interpreted by Verwoerd (1967) to represent the surface expression of a central intrusive plug from which the sheets and veins of carbonatite emanate. Both dolomite and calcite carbonatites are represented with the magnesian variety predominating: calcite carbonatites are restricted to the outer portions of the complex. Verwoerd (1967) described mixed calcite-dolomite carbonatites near the contact between these varieties with the amounts of "accessory calcite" in the dolomite carbonatite increasing towards the calcite carbonatite. Phlogopite, magnetite and apatite are the main accessory phases in the dolomite carbonatite along with sparse sulphides.

\section{Mineralisation}

REE and phosphate mineralisation is hosted in a body of iron oxide-rich apatite-calcite breccia developed at the contact between a major body of carbonatite and pyroxenite near the centre of the complex.

This body initially formed a small, but conspicuous, $20 \mathrm{~m}$ high hill on the predominantly flat local landscape with a trigonometric survey beacon on its highest point. Called "Witkoppie" (white hillock) on early maps, it became known as "Breccia Hill" by geologists and miners during the exploitation of the breccia for phosphate by Goldfields of SA, between 1958 and 1982 (which transformed the hill into a $150 \mathrm{~m}$ deep open pit!). The mined phosphate ore was simply crushed and graded: the high phosphate material $\left(36 \% \mathrm{P}_{2} \mathrm{O}_{5}\right.$ on average) was shipped, untreated, to a smelter for production of thermal phosphate; the balance stored in a series of stockpiles on the mine site. In 2002 FerMinOre Ltd. acquired the property from Goldfields of SA and developed and operated a 2000 tpm plant producing single superphosphate from material drawn from the stockpiles. In 2009 the property was transferred to Glenover Pty Ltd., a subsidiary of FerMinOre, to develop the identified REE and niobium potential of the breccia along with the phosphate.

This breccia is composed of centimetre-scale angular clasts of magnetite (now altered to martite or hematite), set in a reddish matrix cement which is a mixture of apatite, fine iron oxides and minor carbonates (calcite and dolomite). Grain size is highly variable and finer-grained zones and layers free of clasts are common.

The origin of the breccia has been debated: originally Verwoerd (1967) rejected the option of a volcanic vent and interpreted the breccia as resulting from karst sedimentation in a solution cavity, followed by hydrothermal alteration and brecciation by collapse. Later Verwoerd (1986) reconsidered the option that the breccia was forcibly intruded. Recent resource drilling below the base of the pit confirmed that the breccia does not extend at depth. The breccia is currently interpreted 
as the product of dissolution of the carbonatite by sub-solidus fluids - possibly both late magmatic and heated meteoric waters - and collapse of the leached residue. Acidification of the fluids by the dissolution of the volumetrically small, but widespread, sulphide component in the carbonatite is thought to have assisted the breakdown of the carbonate and phosphate phases.

Poly-metallic mineralisation of the breccia is a consequence of enrichment in the lag material remaining from the removal of the major rock phases. Phosphate is largely contributed from primary apatites in the carbonatite and pyroxenite; the REE were liberated from primary REE carbonate phases as well as the apatite, and reprecipitated as rare earth carbonates (synchisite and bastnaesite) and phosphates (secondary monazite and apatite). Two populations of apatite have been identified - low- and high-REE types. REE are also bound in the titano-niobate mineral aeschynite indicating the contribution of components from the pyroxenite (titanium, phosphate andiron) to the final mineralised precipitate. Monazite and REE carbonates host over $50 \%$ of the REE grade; the balance is held, in near equal contributions, in niobates, apatites and an unidentified iron-cerium carbonate phase.

\section{Resource}

Resources were estimated (using the SAMREC criteria) for the breccia ore in the stockpiles and remaining in situ material in the pit: only the REE and phosphate were assessed in the stockpiles but $\mathrm{Nb}$ was also estimated for the in situ ore. The study also provided resource estimates for the carbonatite and pyroxenite intersected in the resource boreholes (the resource and geology report is available at: http:// www.galileoresources.com/projects/Glenover\%20Geological \%20and\%20Resource\%20Report\%203\%20August\%202012.pdf). A total of $221 \mathrm{kt}$ of contained REO remain in unmined in situ breccia ore and on the stockpiles. Full details of the resource are provided in Table 4.

\section{Tantalus (Madagascar)}

\section{Location and Ownership}

The Tantalus Project is located on the Ampasindava Peninsula on the northwest coast of Madagascar (Figures 1 and 18) approximately $50 \mathrm{~km}$ south of the island of Nosy Bé and $580 \mathrm{~km}$ north of the capital, Antananarivo (Gilbertson, 2013). The Tantalus project is unique amongst the advanced REE projects in Africa in that it is claimed to be of the ion-adsorption-clay type. The Tantalus project is owned $100 \%$ by Tantalus Rare Earths AG (http://www.tre-ag.com/).

\section{Geology}

The Tantalus project is located within the sub-volcanic Ambohimirahavavy Alkaline Complex that is a member of the late Oligocene/early Miocene Ampasindava Alkali Province. Uraniumlead zircon age determinations for the complex give dates of $\sim 24 \mathrm{Ma}$ (Estrade et al., 2014a). The complex intruded Jurassic sediments of the Isalo Group: mudstones and siltstones interbedded with sandstones, marls and minor carbonates. Ambohimirahavavy is oval in shape, $20 \times 8 \mathrm{~km}$ in size, and consists of two sub-circular intrusive bodies interpreted as caldera structures; they comprise an association of nepheline syenite and saturated to over-saturated syenites, partially

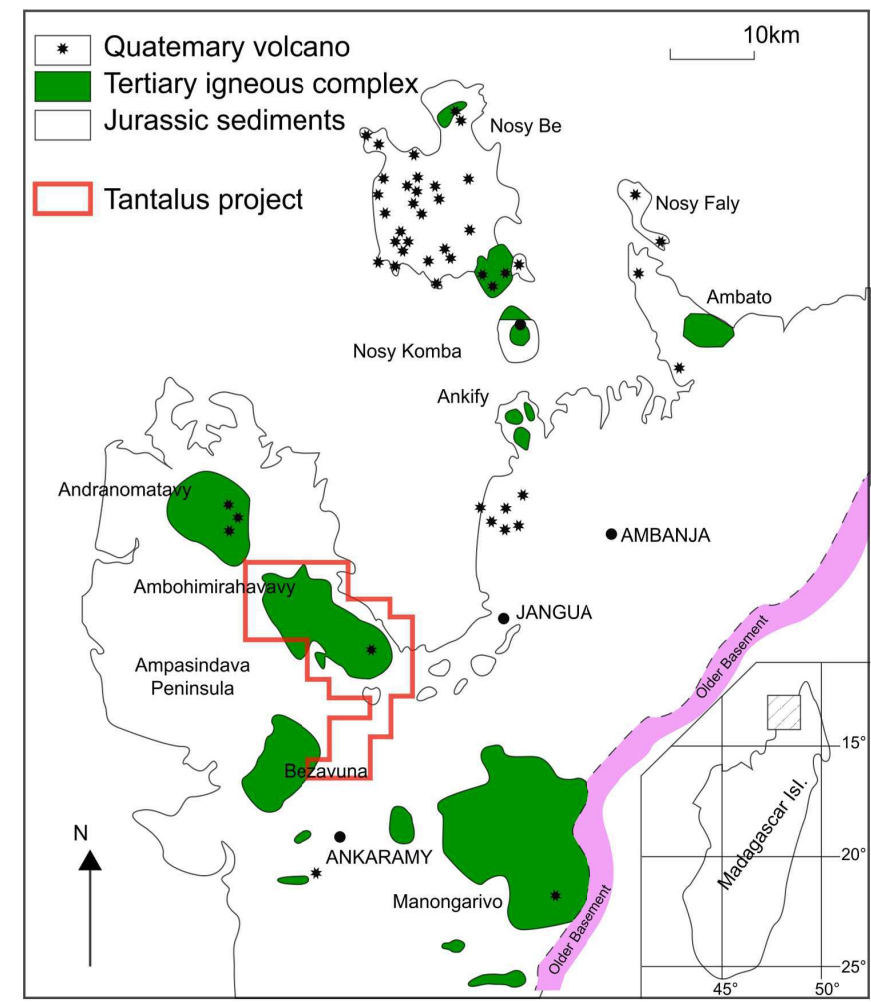

Figure 18: Map showing location and setting of the Tantalus Rare Earth Project in north-west Madagascar (after Desharnais, et al., 2014).

covered by their volcanic equivalents (Estrade et al.,2014; Gilbertson, 2013).

Exploration efforts have focussed on the south-eastern caldera: Ampasibikita. Magnetic and radiometric data suggest the structure is near-circular with a diameter of $\sim 7 \mathrm{~km}$; the caldera is filled with trachytic volcanic/volcaniclastics and the centre is penetrated by a rhyolitic obsidian dome (Estrade et al., 2014; see Figure 19). The outer part of the caldera structure is cut by swarms of dykes of trachyte, microsyenite, trachyphonolite and peralkaline granite composition: the latter, locally called "fasibikitites", are enriched in REE and associated critical metals like tantalum, niobium and zirconium (Desharnais, et al., 2014). Mineralised skarn systems are developed in places where peralkaline granite dykes intersect country rock marls and limestone sediments.

\section{Style of Mineralisation}

REE mineralisation developed in the Ampasibikita peralkaline granite dykes is analogous to that found in similar peralkaline rocks elsewhere (e.g. Khibiny and Lovozero in Kola, Russia; Strange Lake, Canada). At Ampasibikita, REE-bearing phases in the granites include chevkinite, eudialyte, monazite, pyrochlore and zircon; all are fine-grained $(<1 \mathrm{~mm})$, and interpreted as primary magmatic minerals. Contact skarns contain REE-fluorocarbonates (bastnaesite, synchisite, parisite) generated from metasomatic and/or hydrothermal processes (Gilbertson, 2013; Estrade et al., 2014)

The Tantalus REE deposit is located in the regolith developed over the trachytic/syenitic Ampasibikita caldera.

The regolith has an average thickness of $\sim 13 \mathrm{~m}$ but can attain thicknesses of $40 \mathrm{~m}$ (Gilbertson, 2013). The following zones are 


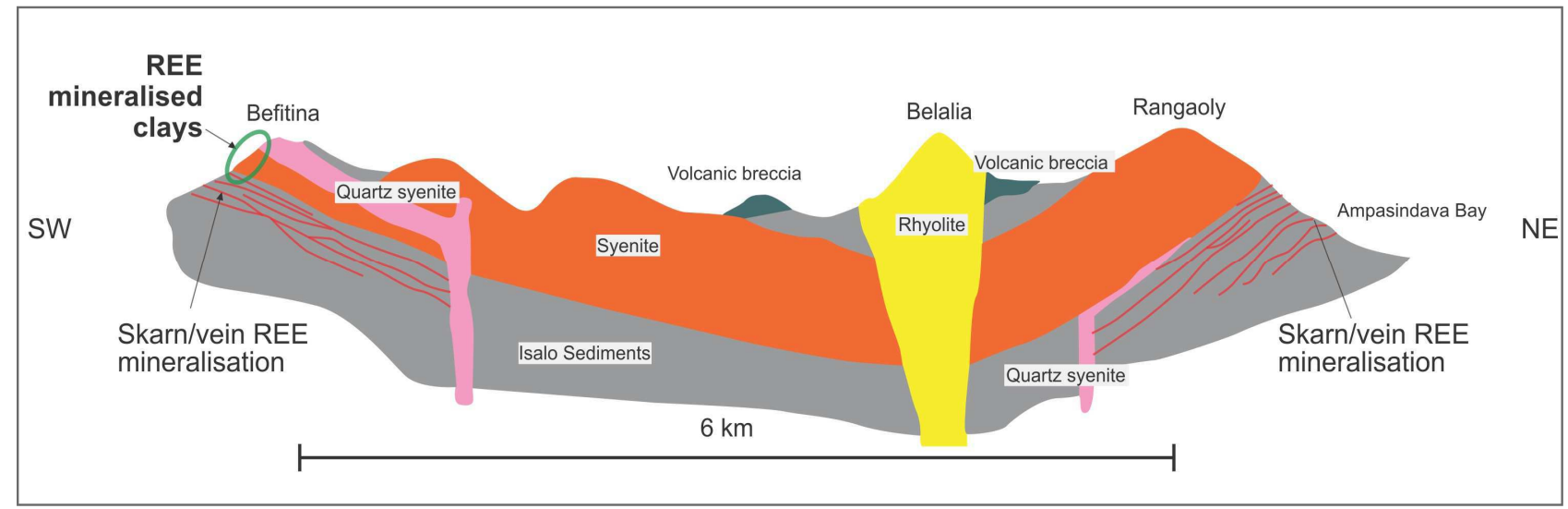

Figure 19: Schematic section through the Ampasibitika intrusive centre showing the setting of the soil-hosted REE mineralisation (after Desharnais, et al., 2014).

recognised within the pedolith portion of the regolith; in top - down sequence:

Soil: typically $<0.5 \mathrm{~m}$ thick;

ferruginous zone: orange-red, homogenous iron-oxide-rich material: thickness variable;

mottled zone: orange-red mottled material of variable thickness; pallid zone: variable thickness of light- to buff-coloured, clayrich material

Basal contacts are gradational into underlying saprolite and saprock.

In the ion-adsorption-type deposits of southern China (Bhao et al., 2008), REE enrichments generally develop at the base of the pedolith section. At Tantalus the REE mineralisation is erratic but generally increases with depth; like the Chinese deposits, the HREE/ LREE tends to increase with depth (Gilbertson, 2013). The regolith also contains a range of relict refractory accessory REEbearing phases which include baddeleyite, eudialyte, pyrochlore and zircon: this is significant as at least some of the REE budget must reside in refractory phases rather than being completely ionicallybound to clay minerals.

\section{Resource}

A preliminary inferred resource was estimated for each of five prospect sub-areas within the project using data from 277 boreholes and 1,000 pits (<10 m depth) (Gilbertson, 2013). Preliminary mineralogical and metallurgical testwork "confirmed the presence of REEs that are ionically adsorbed onto clay minerals" amenable to extraction "using comparatively inert solutions" (Gilbertson, 2013).

Additional pitting was completed that extended the exploration coverage and a revised resource estimate was constructed solely from the laterite and saprolite layers incorporating several refinements to the earlier estimate. The most significant (and novel) refinement being the use of variable cut-off grades for different blocks based on their "amenability to in-situ leaching or tank leaching" to extract REE: factors essentially controlled by the slope of the landsurface (details provided in Besharnais et al., 2014).

It is estimated that over 550,000 tonnes of contained REO exist in the Tantalus Mineral Resource, including 40.1 Mt of Measured Resource at a grade of $0.097 \%$ TREO for 52,200 tonnes of contained REO. Full details of the resource are provided in Table 4.

\section{Steenkampskraal REE-Thorium deposit (South Africa)}

\section{Location and Ownership}

Steenkampskraal is located in the north-western part of the Western Cape Province of South Africa approximately $350 \mathrm{~km}$ north of Cape Town (Figure 1). The deposit was previously mined for thorium and the mine site is owned by Steenkampskraal Monazite Mine (Pty) Limited ("SMM"), a subsidiary of Rare Earth Extraction Co. Ltd. ("Rareco"), now a wholly-owned subsidiary of Great Western Minerals Group (GWMG: TSX.V:GWG; www.gwmg.ca). SMM holds a New Order Mining Right permitting mining operations until 2030.

Much of the following information is derived from NI 43-101 format technical reports available off the GWMG website (http:// www.gwmg.ca/mining-operations/assessment-reports).

\section{Geology}

The Steenkampskraal deposit is hosted within Mesoproterozoic granitoid gneisses near the southern edge of exposure of the Namaqua Province. Younger quartzites and shales of the Vanrhynsdorp Group (550 - $530 \mathrm{Ma}$ ) overlie the gneisses on the Steenkampskraal property. The REE mineralisation is developed in a monazite-apatite vein ore body referred to as the "monazite mineralised zone" or MMZ. The Steenkampskraal occurrence is one of a dozen occurrences of vein-style monazite mineralisation in southern Namaqualand between Steenkampskraal and the Okiep copper district $180 \mathrm{~km}$ to the northwest (Andreoli et al., 1994).

Two suites of granitoids are recognised in the immediate vicinity of the Steenkampskraal deposit. Equigranular and megacrystic granitegneisses make up the bulk of the hosting country rocks and are referred to as the Steenkampskraal Granitic Gneisses. These are cut by units of the Steenkampskraal Intrusive Suite, an assemblage of dykes of alkali granite, granite, and quartz syenite. Some bodies contain orthopyroxene, and locally are charnockite or enderbite in composition; mafic members, such as hypersthenite, anorthosite, and leuconorite have been reported (Hancox and Jones, 2012).

The MMZ REE body is spatially associated with granitoid members of the Steenkampskraal Intrusive Suite and was emplaced between the late stages of the D2/F2 structural event and the initial phase of the D3/F3 event of the Namaqua Orogeny. The latter event 
involved upright folding; in places intense monoclinal folding created axial faults and shear zones that produced the "steep structures" and attendant igneous magmatism associated with the Okiep mineralisation (Clay et al., 2014). Andreoli et al. (1994) argued that the MMZ was emplaced during the F3 structural event; more recent studies reveal that the MMZ is transected and steepened by the $\mathrm{D}_{3}$ and so was injected prior to the formation of the $\mathrm{D}_{3}$ steep structures (Basson et $a l$. , in press). These findings are consistent with the new date for the crystallisation of the MMZ of $1046 \pm 7.5 \mathrm{Ma}$ (Knoper, 2010).

Sub-vertical normal faults associated with the later Neoproterozoic tectonism reactivated older structures causing localised brecciation of the Namaqua gneisses and displaced and deformed the MMZ.

\section{Mineralisation}

The MMZ appears as a thin lenticular-shaped lode, having an average overall thickness of about $0.6 \mathrm{~m}$, a strike-length of about 400 meters at the surface, and a known southerly down-dip extension of at least 450 meters. Historic underground mine development showed the MMZ to vary in thickness between $0.2 \mathrm{~m}$ and $4.5 \mathrm{~m}$ with an average thickness of $0.5 \mathrm{~m}$. Recent resource drilling confirmed the presence of significant vein thicknesses with a maximum of $5.67 \mathrm{~m}$ (true thickness) being intersected (Hancox and Jones, 2012). Significantly, contacts of the MMZ with host gneisses are typically sharp and distinct, and minimal monazite mineralisation $(<1 \%)$ occurs within the hangingwall or footwall. The morphology of the MMZ is fundamentally structurally controlled. The deposit is bounded in the east and west by major faults which effectively close off the mineralisation along strike but current understanding of the structural and geological framework suggests a strong potential for further mineralisation "displaced" beyond these faults and has been the focus of exploration efforts by GWMG (Clay et al., 2014).

Four broad petrographic types of mineralisation are recognised in the MMZ and these are summarised in Table 3. The MMZ is composed of approximately $40 \%$ monazite and other REE phases, along with a gangue assemblage of quartz, feldspar, iron-rich chlorite, iron oxides, ilmenite, sulphides (pyrite, chalcopyrite and/or galena) and thorite.Monazite accounts for $>91 \%$ of the total REE content; the remainder being held mostly in allanite and xenotime.Variations in TREO grades reflect the degree of dilution by REE-barren gangue phases (Clay et al., 2014).

Several different models have been proposed for the origin of the
Steenkampskraal mineralisation and there is presently no consensus on its genesis.

Early workers favoured a hydrothermal origin for the MMZ whereas Andreoli et al. (1994) argued that the monazite body was of magmatic origin, crystallising from an immiscible phosphate + sulphide + oxide magmatic liquid, analogous to the mode of formation of nelsonite. On the basis of data collected during the feasibility study on the project, Clay et al. (2014) concluded that the primary mineralising fluid was generated by "regional magmatic process", culminating in the production of an immiscible liquid (either magma or brine) enriched in phosphate and REE (along with other elements) that was emplaced under ductile-brittle conditions at granulite facies metamorphic temperatures and pressures. The vein was affected by syn- and post-emplacement metamorphic and hydrothermal events which introduced magnetite and sulphides and other alteration assemblages (Clay et al., 2014).

\section{Resource}

The Feasibility Study for the Steenkampskraal project (Clay et al., 2014) declared a total REE resource for the project of 665,000 tonnes at an average grade of 14.0\% TREO for 93,100 tonnes of contained REO. This composite resource combines in situ ore with material in historic tailings dams: a breakdown of the resource classifications and grades is provided in Table 4.

Steenkampskraal was the first of the African REE projects to complete a Feasibility Study.

\section{Gakara (Burundi)}

\section{Location and Ownership}

The Karonge / Gakara vein system occurs in the west of Burundi, approximately $20 \mathrm{~km}$ southeast of the capital Bujumbura and 12$14 \mathrm{~km}$ east of the shores of Lake Tanganyika (Figure 1). Rainbow Rare Earths (www.rainbowrareearths.com), a private company, holds $85 \%$ of the Gakara project.

\section{Geology and Mineralisation}

The Karonge/Gakara REE vein mineralisation was discovered in 1936 and was mined between 1948 and 1978, producing a total of

Table 3: Summary of petrographic ore types recognized within the MMZ of the Steenkampskraal deposit.

\begin{tabular}{|l|l|l|}
\hline Type & Name & Description \\
\hline Type 1 & Phosphate-rich "ore" & $\begin{array}{l}\text { Provides the bulk of the economic-grade material, with phosphate minerals (monazite and apatite) } \\
\text { comprising up to } 80 \% \text { of the ore mass. Sulphides, oxides, and silicates make up the remainder in } \\
\text { decreasing order of abundance. }\end{array}$ \\
\hline Type 2 & Oxide-rich "ore" & $\begin{array}{l}\text { Monazite-bearing hercynite-magnetite-rich bands in or adjacent to the phosphate-rich ore. Relatively } \\
\text { uncommon assemblage. }\end{array}$ \\
\hline Type 3 & Feldspathic "ore" & $\begin{array}{l}\text { Includes a broad range of silicate and phosphate minerals - usually as stringers of magnetite and } \\
\text { monazite in a plagioclase-quartz matrix. Chlorite, zoisite and allanite extensively replace plagioclase, } \\
\text { biotite and monazite. }\end{array}$ \\
\hline Type 4 & Siliceous "ore" & $\begin{array}{l}\text { Co-exists, and is banded, with massive monazite. Commonly grades into lenticular masses of dark } \\
\text { quartz rock (up to 0.50 m thick) that are frequently developed at the contacts between tonalities and } \\
\text { the phosphate-rich ore. Comprises monazite, minor apatite, oxides and sulphides along with small } \\
\text { (2-3 mm) disseminated nodules of quartz, monazite, apatite, zircon, skeletal biotite and chlorite } \\
\text { pseudomorphs after garnet. }\end{array}$ \\
\hline
\end{tabular}


Table 4: Details of the resources and reserves declared for the REE projects under review

\begin{tabular}{|c|c|c|c|c|c|c|c|c|c|c|c|c|c|c|c|c|c|c|c|}
\hline \multirow[t]{2}{*}{ Deposit } & \multirow{2}{*}{$\begin{array}{l}\text { Classi- } \\
\text { fication }\end{array}$} & \multirow{2}{*}{$\begin{array}{c}\text { Ore } \\
\text { Tonnes } \\
\text { (millions) }\end{array}$} & \multirow{2}{*}{$\begin{array}{c}\text { Grade } \\
(\%)\end{array}$} & \multirow{2}{*}{$\begin{array}{c}\text { Contained } \\
\text { REO } \\
(1,000 \mathrm{t})\end{array}$} & \multicolumn{15}{|c|}{ Rare Earth Oxide proportions (\%) } \\
\hline & & & & & $\mathrm{La}_{2} \mathrm{O}_{3}$ & $\mathrm{CeO}_{2}$ & $\mathrm{Pr}_{6} \mathrm{O}_{11}$ & $\mathrm{Nd}_{2} \mathrm{O}_{3}$ & $\mathrm{Sm}_{2} \mathrm{O}_{3}$ & $\mathrm{Eu}_{2} \mathrm{O}_{3}$ & $\mathrm{Gd}_{2} \mathrm{O}_{3}$ & $\mathrm{~Tb}_{4} \mathrm{O}_{7}$ & $\mathrm{Dy}_{2} \mathrm{O}_{3}$ & $\mathrm{Ho}_{2} \mathrm{O}_{3}$ & $\mathrm{Er}_{2} \mathrm{O}_{3}$ & $\mathrm{Tm}_{2} \mathrm{O}_{3}$ & $\mathrm{Yb}_{2} \mathrm{O}_{3}$ & $\mathrm{Lu}_{2} \mathrm{O}_{3}$ & $\mathrm{Y}_{2} \mathrm{O}_{3}$ \\
\hline Kangankunde & Inferred & 2.53 & 4.24 & 107 & 29.77 & 49.73 & 4.69 & 14.02 & 1.05 & 0.19 & 0.36 & 0.07 & 0.08 & 0.01 & 0.02 & 0.00 & 0.01 & 0.00 & 0.00 \\
\hline Songwe & $\begin{array}{l}\text { Indicated } \\
\text { Inferred }\end{array}$ & $\begin{array}{l}13.2 \\
18.6 \\
\end{array}$ & $\begin{array}{l}1.62 \\
1.38 \\
\end{array}$ & $\begin{array}{l}213 \\
256 \\
\end{array}$ & 24.63 & 44.60 & 4.77 & 16.35 & 2.38 & 0.57 & 1.35 & 0.16 & 0.79 & 0.13 & 0.30 & 0.04 & 0.22 & 0.03 & 3.67 \\
\hline $\begin{array}{l}\text { Songwe Mineral } \\
\text { Reserves }\end{array}$ & Probable & 8.48 & 1.60 & 136 & 24.63 & 44.60 & 4.77 & 16.35 & 2.38 & 0.57 & 1.35 & 0.16 & 0.79 & 0.13 & 0.30 & 0.04 & 0.22 & 0.03 & 3.67 \\
\hline $\begin{array}{l}\text { Wigu Hill (Twiga 1\%) } \\
\text { Wigu Hill (Twiga 3\%) } \\
\text { Wigu Hill (Tembo) }\end{array}$ & $\begin{array}{l}\text { Inferred } \\
\text { Inferred } \\
\text { Inferred }\end{array}$ & $\begin{array}{c}1.93 \\
0.47 \\
1.1\end{array}$ & $\begin{array}{l}2.69 \\
5.26 \\
1.83\end{array}$ & $\begin{array}{l}51.9 \\
24.7 \\
20.1\end{array}$ & $\begin{array}{l}38.96 \\
38.13\end{array}$ & $\begin{array}{l}47.47 \\
48.59\end{array}$ & $\begin{array}{l}3.58 \\
3.74\end{array}$ & $\begin{array}{l}8.96 \\
8.60\end{array}$ & $\begin{array}{l}0.45 \\
0.37\end{array}$ & $\begin{array}{l}0.12 \\
0.12\end{array}$ & $\begin{array}{l}0.17 \\
0.17\end{array}$ & $\begin{array}{l}0.02 \\
0.02\end{array}$ & $\begin{array}{l}0.06 \\
0.06\end{array}$ & $\begin{array}{l}0.01 \\
0.01\end{array}$ & $\begin{array}{l}0.01 \\
0.01\end{array}$ & $\begin{array}{l}0.00 \\
0.00\end{array}$ & $\begin{array}{l}0.01 \\
0.01\end{array}$ & $\begin{array}{l}0.00 \\
0.00\end{array}$ & $\begin{array}{l}0.17 \\
0.18\end{array}$ \\
\hline Lofdal & $\begin{array}{l}\text { Indicated } \\
\text { Inferred }\end{array}$ & $\begin{array}{l}2.88 \\
3.28 \\
\end{array}$ & $\begin{array}{l}0.32 \\
0.27 \\
\end{array}$ & $\begin{array}{l}9.22 \\
8.86 \\
\end{array}$ & 5.40 & 9.80 & 1.10 & 4.00 & 1.60 & 0.80 & 4.00 & 1.00 & 7.40 & 1.60 & 4.80 & 0.70 & 4.40 & 0.60 & 52.80 \\
\hline Ngualla Project (3\%) & $\begin{array}{l}\text { Measured } \\
\text { Indicated } \\
\text { Inferred } \\
\end{array}$ & $\begin{array}{r}27 \\
13 \\
1.7 \\
\end{array}$ & $\begin{array}{l}4.33 \\
3.99 \\
3.56 \\
\end{array}$ & $\begin{array}{c}1,169 \\
519 \\
60.5 \\
\end{array}$ & 27.60 & 48.20 & 4.73 & 16.60 & 1.60 & 0.30 & 0.61 & 0.05 & 0.08 & 0.01 & 0.03 & 0.00 & 0.01 & 0.00 & 0.20 \\
\hline Ngualla Bastnaesite (3\%) & $\begin{array}{l}\text { Measured } \\
\text { Indicated } \\
\text { Inferred }\end{array}$ & $\begin{array}{c}19 \\
2.9 \\
0.11 \\
\end{array}$ & $\begin{array}{c}4.53 \\
4.62 \\
4.1 \\
\end{array}$ & $\begin{array}{l}861 \\
134 \\
4.5 \\
\end{array}$ & 27.60 & 48.20 & 4.73 & 16.60 & 1.60 & 0.30 & 0.61 & 0.05 & 0.08 & 0.01 & 0.03 & 0.00 & 0.01 & 0.00 & 0.20 \\
\hline $\begin{array}{l}\text { Ngualla Mineral } \\
\text { Reserve }\end{array}$ & Probable & 21.6 & 4.54 & 981 & 27.60 & 48.20 & 4.73 & 16.60 & 1.60 & 0.30 & 0.61 & 0.05 & 0.08 & 0.01 & 0.03 & 0.00 & 0.01 & 0.00 & 0.20 \\
\hline Mrima Hill & $\begin{array}{l}\text { Indicated } \\
\text { Inferred }\end{array}$ & $\begin{array}{l}48.7 \\
110.7\end{array}$ & $\begin{array}{c}4.4 \\
3.61\end{array}$ & $\begin{array}{l}2,143 \\
3,996\end{array}$ & $\begin{array}{l}27.50 \\
25.70\end{array}$ & $\begin{array}{l}43.20 \\
42.80\end{array}$ & $\begin{array}{l}4.50 \\
4.50\end{array}$ & $\begin{array}{l}14.90 \\
15.10\end{array}$ & $\begin{array}{l}2.00 \\
2.10\end{array}$ & $\begin{array}{l}0.50 \\
0.60\end{array}$ & $\begin{array}{l}1.40 \\
1.60\end{array}$ & $\begin{array}{l}0.20 \\
0.20\end{array}$ & $\begin{array}{l}0.80 \\
1.00\end{array}$ & $\begin{array}{l}0.10 \\
0.20\end{array}$ & $\begin{array}{l}0.30 \\
0.40\end{array}$ & $\begin{array}{l}0.00 \\
0.10\end{array}$ & $\begin{array}{l}0.20 \\
0.30\end{array}$ & $\begin{array}{l}0.00 \\
0.00\end{array}$ & $\begin{array}{l}4.20 \\
5.40\end{array}$ \\
\hline $\begin{array}{l}\text { Zandkopsdrift Mineral } \\
\text { Resource }\end{array}$ & $\begin{array}{l}\text { Measured } \\
\text { Indicated } \\
\text { Inferred } \\
\end{array}$ & $\begin{array}{c}23.0 \\
22.7 \\
1.1 \\
\end{array}$ & $\begin{array}{l}2.07 \\
1.73 \\
1.52 \\
\end{array}$ & $\begin{array}{l}476 \\
393 \\
16.5 \\
\end{array}$ & $\begin{array}{l}26.24 \\
26.23 \\
26.26 \\
\end{array}$ & $\begin{array}{l}44.14 \\
44.14 \\
44.12 \\
\end{array}$ & $\begin{array}{l}4.63 \\
4.62 \\
4.66 \\
\end{array}$ & $\begin{array}{l}15.68 \\
15.71 \\
15.69 \\
\end{array}$ & $\begin{array}{l}2.17 \\
2.20 \\
2.17 \\
\end{array}$ & $\begin{array}{l}0.58 \\
0.58 \\
0.53 \\
\end{array}$ & $\begin{array}{l}1.30 \\
1.33 \\
1.31 \\
\end{array}$ & $\begin{array}{l}0.14 \\
0.17 \\
0.13 \\
\end{array}$ & $\begin{array}{l}0.72 \\
0.69 \\
0.72 \\
\end{array}$ & $\begin{array}{l}0.10 \\
0.12 \\
0.13 \\
\end{array}$ & $\begin{array}{l}0.29 \\
0.29 \\
0.26 \\
\end{array}$ & $\begin{array}{l}0.05 \\
0.06 \\
0.07 \\
\end{array}$ & $\begin{array}{l}0.19 \\
0.17 \\
0.20\end{array}$ & $\begin{array}{l}0.05 \\
0.00 \\
0.00\end{array}$ & $\begin{array}{l}3.71 \\
3.70 \\
3.74 \\
\end{array}$ \\
\hline $\begin{array}{l}\text { Zandkopsdrift Mineral } \\
\text { Reserve }\end{array}$ & $\begin{array}{l}\text { Proven } \\
\text { Probable }\end{array}$ & $\begin{array}{l}14.93 \\
26.19\end{array}$ & $\begin{array}{l}2.21 \\
1.75\end{array}$ & $\begin{array}{l}331 \\
458\end{array}$ & $\begin{array}{l}25.38 \\
25.33\end{array}$ & $\begin{array}{l}44.04 \\
44.03\end{array}$ & $\begin{array}{l}4.61 \\
4.63\end{array}$ & $\begin{array}{l}15.90 \\
15.89\end{array}$ & $\begin{array}{l}2.26 \\
2.29\end{array}$ & $\begin{array}{l}0.59 \\
0.57\end{array}$ & $\begin{array}{l}1.40 \\
1.43\end{array}$ & $\begin{array}{l}0.18 \\
0.17\end{array}$ & $\begin{array}{l}0.77 \\
0.80\end{array}$ & $\begin{array}{l}0.14 \\
0.11\end{array}$ & $\begin{array}{l}0.32 \\
0.34\end{array}$ & $\begin{array}{l}0.05 \\
0.06\end{array}$ & $\begin{array}{l}0.23 \\
0.23\end{array}$ & $\begin{array}{l}0.05 \\
0.06\end{array}$ & $\begin{array}{l}4.11 \\
4.12\end{array}$ \\
\hline Xiluvo & Indicated & 1.11 & 2.05 & 22.8 & 22.00 & 46.00 & 4.90 & 17.00 & 2.40 & 0.70 & 1.70 & 0.20 & 0.90 & 0.14 & 0.32 & 0.03 & 0.20 & 0.02 & 4.00 \\
\hline $\begin{array}{l}\text { Glenover (Stockpiles) } \\
\text { Glenover (In situ Ore) } \\
\text { Glenover (In situ Ore) }\end{array}$ & $\begin{array}{l}\text { Inferred } \\
\text { Indicated } \\
\text { Inferred } \\
\end{array}$ & $\begin{array}{l}2.69 \\
7.41 \\
0.27 \\
\end{array}$ & $\begin{array}{c}1.94 \\
2.2 \\
2.16 \\
\end{array}$ & $\begin{array}{c}52.2 \\
163 \\
5.83 \\
\end{array}$ & $\begin{array}{l}19.1 \\
16.2\end{array}$ & $\begin{array}{l}45.7 \\
44.6\end{array}$ & $\begin{array}{l}5.27 \\
5.89\end{array}$ & $\begin{array}{l}21.0 \\
22.5\end{array}$ & $\begin{array}{l}3.03 \\
3.66\end{array}$ & $\begin{array}{l}0.74 \\
0.93\end{array}$ & $\begin{array}{l}1.67 \\
2.14\end{array}$ & $\begin{array}{l}0.17 \\
0.22\end{array}$ & $\begin{array}{l}0.65 \\
0.81\end{array}$ & $\begin{array}{l}0.09 \\
0.11\end{array}$ & $\begin{array}{l}0.17 \\
0.20\end{array}$ & $\begin{array}{l}0.02 \\
0.02\end{array}$ & $\begin{array}{l}0.09 \\
0.09\end{array}$ & $\begin{array}{l}0.01 \\
0.01\end{array}$ & $\begin{array}{l}2.30 \\
2.64\end{array}$ \\
\hline Tantalus & $\begin{array}{l}\text { Measured } \\
\text { Indicated } \\
\text { Inferred } \\
\end{array}$ & $\begin{array}{c}40.1 \\
157.6 \\
430 \\
\end{array}$ & $\begin{array}{l}0.097 \\
0.088 \\
0.089 \\
\end{array}$ & $\begin{array}{c}38.9 \\
138.7 \\
382.7 \\
\end{array}$ & $\begin{array}{l}24.70 \\
22.20 \\
25.00 \\
\end{array}$ & $\begin{array}{l}32.30 \\
36.90 \\
35.80 \\
\end{array}$ & $\begin{array}{l}4.80 \\
4.42 \\
4.67 \\
\end{array}$ & $\begin{array}{l}16.30 \\
14.90 \\
15.40 \\
\end{array}$ & $\begin{array}{l}2.78 \\
2.65 \\
2.46 \\
\end{array}$ & $\begin{array}{l}0.29 \\
0.31 \\
0.27 \\
\end{array}$ & $\begin{array}{l}2.36 \\
2.05 \\
1.97 \\
\end{array}$ & $\begin{array}{l}0.34 \\
0.32 \\
0.29 \\
\end{array}$ & $\begin{array}{l}1.96 \\
1.90 \\
1.66 \\
\end{array}$ & $\begin{array}{l}0.37 \\
0.38 \\
0.32 \\
\end{array}$ & $\begin{array}{l}1.06 \\
1.09 \\
0.95 \\
\end{array}$ & $\begin{array}{l}0.14 \\
0.16 \\
0.13 \\
\end{array}$ & $\begin{array}{l}0.95 \\
1.02 \\
0.89 \\
\end{array}$ & $\begin{array}{l}0.14 \\
0.15 \\
0.13 \\
\end{array}$ & $\begin{array}{l}11.60 \\
11.50 \\
10.10\end{array}$ \\
\hline Steenkampskraal & $\begin{array}{l}\text { Measured } \\
\text { Indicated } \\
\text { Inferred } \\
\end{array}$ & $\begin{array}{c}0.085 \\
0.474 \\
0.06 \\
\end{array}$ & $\begin{array}{l}19.5 \\
14.1 \\
10.4 \\
\end{array}$ & $\begin{array}{c}16.58 \\
66.8 \\
6.24 \\
\end{array}$ & 20.80 & 45.20 & 5.10 & 18.00 & 2.90 & 0.07 & 2.00 & 0.21 & 0.99 & 0.14 & 0.29 & 0.03 & 0.13 & 0.01 & 4.10 \\
\hline Steenkampskraal Historic & Indicated & 0.046 & 7.2 & 3.312 & & & & & & & & & & & & & & & \\
\hline
\end{tabular}


5,000 tonnes of bastnaesite-rich ore grading over 50\% TREO. Gakara was the first REE producer in Africa.

Gakara is hosted by Mesoproterozoic metasediments (quartzites, and pelites) which are surrounded by Mesoproterozoic tonalites and granites.

The Gakara deposit consists of a structurally-controlled stockwork vein system which occurs in several NE-SW trending zones, possibly related to fault zones on a major anticlinal structure (Van Wambeke, 1977). Vein widths vary from $3-30 \mathrm{~cm}$ and are composed principally of bastnaesite and monazite. The bastnaesite has been dated at $586.8 \pm 3.7 \mathrm{Ma}$ (Ba-La technique: Nakai et al.,1988) implying that the mineralisation significantly post-dates the younger granitic pegmatites in the region. Most workers relate the REE vein mineralisation to a late-stage hydrothermal event related to a carbonatitic source (Van Wambeke, 1977; Brinckmann and Lehmann, 1983; Lehmann et al., 1994) despite the fact that the closest known carbonatite, Matongo, lies $60 \mathrm{~km}$ to the north.

Initial REE mineralisation was of coarse-grained bastnaesite which was later brecciated, allowing ingress of phosphatic fluids that metasomatically transformed the bastnaesite to microcrystalline monazite. A range of mineralisation types were generated in response to the intensity of the metasomatism from pure, massive bastnaesite (massive mineralisation), through mixed bastnaesite-monazite to monazite-dominated (breccia) mineralisation (Brinckmann and Lehmann, 1983). Accompanying gangue mineral phases are baryte, quartz, microcline, biotite, pyrite, molybdenite, and galena.

\section{Resource}

No modern resource estimate is available for the REE resources at Gakara.

Since 2011 Rainbow Rare Earths have completed a mapping and sampling programme to define the true distribution and extent of the REE veining across the Gakara property. They report finding 520 new in situ surface occurrences of REE veins, significantly extending the known extent of the mineralisation. In addition, they claim that 5 of these new prospects contain veins substantially thicker - up to $50 \mathrm{~cm}$ (company website) - than those found in the historically explored areas. A NI 43-101 compliant "mineral inventory" has apparently been compiled but is not in the public domain.

\section{Summary Discussion}

The mineralisation style and stage of project development of the 13 African rare earth metal deposits are summarised in Table 5. For many of these REE deposits, little detailed geological and/or petrological research has been done on the complexes hosting them. Having identified the deposit and acquired the necessary regulatory permissions, the focus of an exploration company (most being listed entities and responsible to shareholders) is always to acquire the data necessary to establish mineral resources and ore reserves to complete the necessary feasibility studies - acquiring a geological understanding of the deposit generally has a lower priority. Research projects have begun at a few projects but are mostly too recent for new findings to be published; some new research results remain under embargo so are not yet in the public domain. As results from these studies become public, many of the genetic models are likely to be modified or replaced with improved options.

Details of the mineral resources or ore reserves defined on the deposits under review are provided in Table 4 along with the relative proportions of each rare earth oxide. The TREO grade of the deposits is compared to size - as tonnes of contained REO - in Figure 20. Marker lines are included on the figure at contained REO values of 100 and $200 \mathrm{kt}$-TREO contents that will provide 20 years of project

Table 5: Summary of mineralisation style and stage of development of the African REE deposits.

\begin{tabular}{|c|c|c|c|}
\hline REE Deposit & Host/source & Mineralisation & $\begin{array}{l}\text { Stage of development of project } \\
\text { (January 2015) }\end{array}$ \\
\hline Kangankunde & Carbonatite & Magmatic-Hydrothermal & Resource (Inferred); development halted \\
\hline Songwe & Carbonatite + fenite & Magmatic-Hydrothermal & PFS Study (Reserves) \\
\hline Nkombwa Hill & Carbonatite & Magmatic-Hydrothermal & Exploration \\
\hline Wigu Hill & Carbonatite & Magmatic-Hydrothermal & Resource (Indicated and Inferred) \\
\hline Lofdal & Carbonatite? & Hydrothermal & PEA Study (Indicated and Inferred) \\
\hline Ngualla Hill & Carbonatite & Epigenetic- residual soil deposit & PFS Study (Reserves) \\
\hline Mrima Hills & Carbonatite & Epigenetic- residual soil deposit & $\begin{array}{l}\text { Resource (Indicated and Inferred); } \\
\text { development halted }\end{array}$ \\
\hline Zandkopsdrift & $\begin{array}{l}\text { Mica-carbonate breccia } \\
\& \text { "REE carbonatite" }\end{array}$ & Epigenetic- residual soil deposit & PFS Study (Reserves) \\
\hline Xiluvo & Carbonatite & Epigenetic- residual soil deposit & Resource (Indicated); development abandoned \\
\hline Glenover & Carbonatite + pyroxenite & Epigenetic- karst solution breccia & PEA Study (Indicated and Inferred) \\
\hline Tantalus & Syenite + skarn & Epigenetic- adsorption clays & PEA Study (Measured, Indicated and Inferred) \\
\hline Gakara & Carbonatite?? & Vein & Exploration \\
\hline Steenkampskraal & $\begin{array}{l}\text { Unidentified } \\
\text { magmatic? } \\
\text { metamorphic? }\end{array}$ & Vein & $\begin{array}{l}\text { Feasibility Study (Measured, Indicated and } \\
\text { Inferred) }\end{array}$ \\
\hline
\end{tabular}

PEA: preliminary economic assessment; PFS: preliminary feasibility study. 


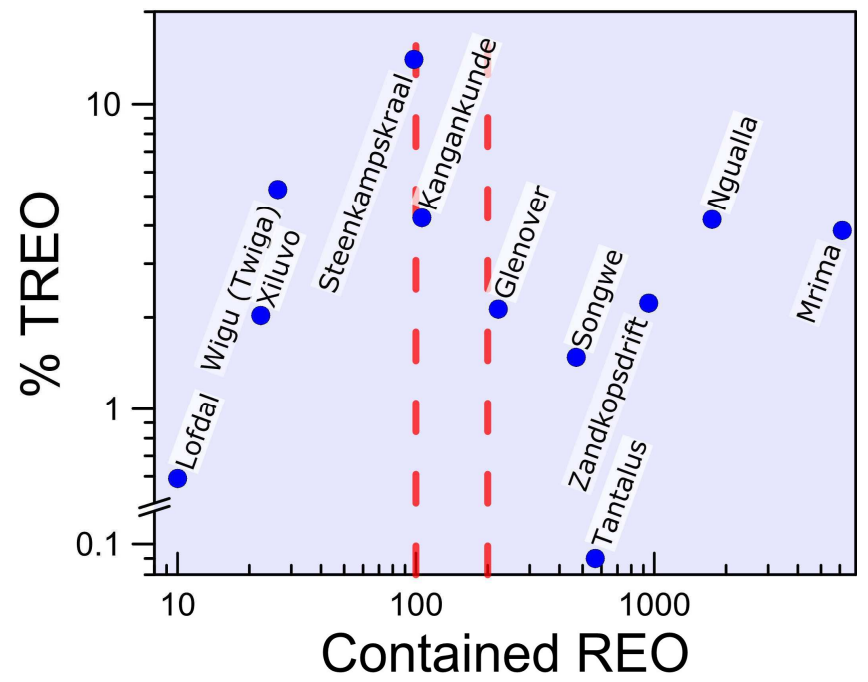

(kt)

Figure 20: Plot of contained in situ REO against TREO grade for the 11 African deposits with declared resources. The vertical dashed lines mark 100,000 and 200,000 tonnes of contained REO, respectively, which would provide a 20 year life of project at annual production/extraction rates of 5,000 and 10,000 tonnes per annum, respectively (discussed in text).

life at annual production levels of 5,000 $\mathrm{t}$ and 10,000 $\mathrm{t}$ respectively; the magnitude of production generally required for a non-Chinese operation.

Carbonatites are the source of, and/or host to, the REE mineralisation in at least 10 of the deposits reviewed; with magnesian, iron-rich dolomitic varieties dominating in all but 3 of them. As a consequence of the incongruent melting of dolomite at crustal pressures, calcite is the early, high temperature liquidus phase in magnesian carbonatite magmas; dolomite only crystallising from the magma at temperatures below $\sim 815^{\circ} \mathrm{C}$ (Harmer and Gittins, 1998). The REE mineralised magnesian carbonatites thus represent relatively

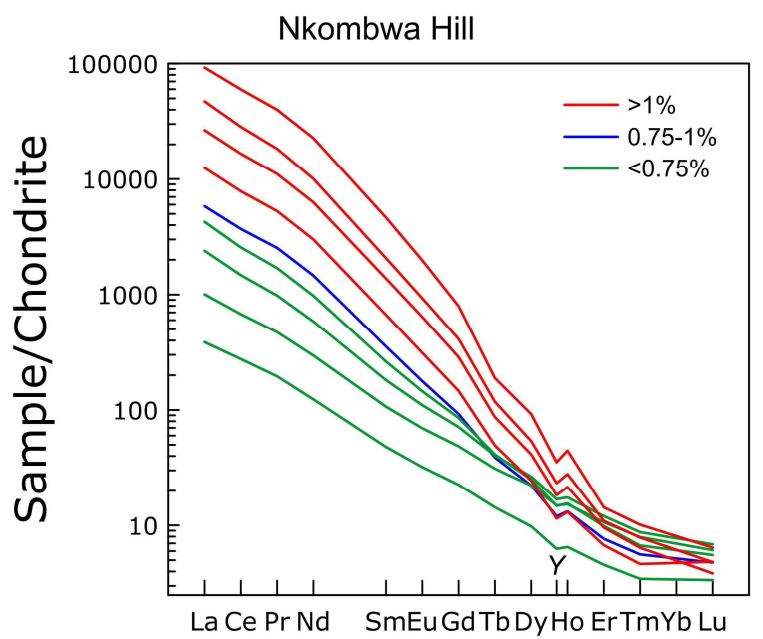

evolved fractions of each complex.

Figure 21 illustrates the changes in relative concentrations of individual REE as TREO concentrations increase in the magnesian carbonatites from the Nkombwa Hill Complex. The plotted averages are derived from an unpublished dataset of assays on over 1,600 kilogram-scale exploration samples and span a range in TREO concentrations from below $0.1 \%$, to over $20 \%$ TREO. The normalised REE patterns in Figure 21(a) are broadly consistent but show a progressive increase in LREE relative to HREE (reflected in a "steepening" in slope of the pattern) with increasing grade. This effect is quantified in Figure 21(b) using the ratio of Nd, a LREE, to Dy, a HREE: both elements being critical constituents of the Nd-Fe-B high strength permanent magnets, and are in high demand. Increases in the REE grade can be comfortably ascribed to magmatic fractionation processes for TREO grades up to $1 \%$; above these levels hydrothermal processes are likely to be active.

The economic implications of the variation in the relative contents of LREE and HREE in ore zones will be appreciated when the massive range in the trading price of different RE oxides (presented in Table 6) is considered. The more "fractionated" the REE pattern, the lower the intrinsic value of the contained REE package. The economic attractiveness or viability of an REE deposit is not solely a matter of tonnes and grade; nor of mining method - whether an REE deposit will ultimately produce saleable rare earth products will depend on whether the REE-bearing phases can, economically: be liberated from their matrix, physically concentrated and brought into solution; have the REE extracted as a group free of contaminants, and refined to $>99 \%$ pure chemical form of the individual REE for sale (generally as oxides, chlorides or metals). Essentially the successful development of an REE project to production is as much a chemical engineering challenge as a geological or mining one.

The demand for the HREE Ho to $\mathrm{Lu}$ is limited as their use is restricted to niche applications; as such they are seldom if ever included in off-take agreements. No value is assigned to them when evaluating the economics of an REE deposit (Prices from Asian Metal Pages www.asianmetal.com).

Each combination of source rock and mineralising process imparts

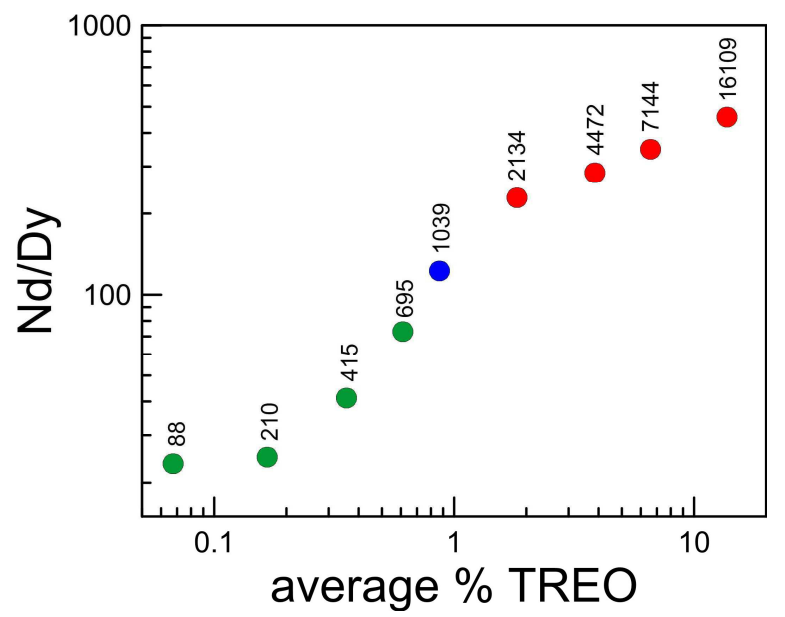

Figure 21: Plots illustrating the fractionation of REE distribution during magmatic/hydrothermal evolution of the Nkombwa Hill carbonatite. (a) chondrite-normalised REE plot of averaged compositional ranges of analyses of over 1,600 exploration samples spanning TREO compositions from below $0.1 \%$ to over $20 \%$ (individual traces are averages for the ranges $-<0.75 \%:<0.1,0.1-0.3,0.3-0.5$ and 0.5-0.75; $>1 \%$ : 1-3, 3-5, 5-10, >10). (b) change in Nd/Dy ratio with increasing total REE grade for the range averages shown in (a); labels provide the ppm Nd concentration for each average. 
Table 6. Prices for 10 of the REO as traded between June 2013 and February 2015 (values are US\$ per kg pure oxide).

\begin{tabular}{|l|cccccccccc|}
\cline { 2 - 9 } \multicolumn{1}{c|}{} & $\mathrm{La}_{2} \mathrm{O}_{3}$ & $\mathrm{CeO}_{2}$ & $\mathrm{Pr}_{6} \mathrm{O}_{11}$ & $\mathrm{Nd}_{2} \mathrm{O}_{3}$ & $\mathrm{Sm}_{2} \mathrm{O}_{3}$ & $\mathrm{Eu}_{2} \mathrm{O}_{3}$ & $\mathrm{Gd}_{2} \mathrm{O}_{3}$ & $\mathrm{~Tb}_{4} \mathrm{O}_{7}$ & $\mathrm{Dy}_{2} \mathrm{O}_{3}$ & $\mathrm{Y}_{2} \mathrm{O}_{3}$ \\
\hline 25 June 2013 & 7.30 & 7.30 & 74.50 & 61.50 & 7.30 & 825 & 20.75 & 700 & 475 & 20.00 \\
10 June 2014 & 5.60 & 5.50 & 120.50 & 69.50 & 7.10 & 855 & 22.67 & 700 & 415 & 48.88 \\
5 February 2015 & 4.00 & 3.55 & 95.50 & 58.50 & 3.50 & 495 & 76.50 & 695 & 335 & 55.50 \\
\hline
\end{tabular}

The demand for the HREE Ho to Lu is limited as their use is restricted to niche applications; as such they are seldom if ever included in off-take agreements. No value is assigned to them when evaluating the economics of an REE deposit. (Prices from Asian Metal Pages www.asianmetal.com).

a different relative distribution of the individual REO in the resulting deposit. Chondrite-normalised plots are used to compare the resource REO distributions in each deposit in Figure 22 (a) - (d); for Nkombwa, where no resource has yet been defined, averages have been used (the four $>1 \%$ groups in Figure 21; also see caption to Figure 22(a)). Each plot has been drawn with identical scaling to aid visual comparison.

The REE variations between the four carbonatite-hosted deposits mineralised through magmatic/hydrothermal processes Kangankunde, Songwe, Wigu and Nkombwa - are shown in Figure 22(a). The normalised REE traces have shapes that are typical of carbonatites: steep, high LREE/HREE profiles with no Eu anomaly.
The "bumpy" nature of the Kangankunde trace - due to apparent "positive anomalies" at $\mathrm{Tb}$ and $\mathrm{Tm}$ - is almost certainly a consequence of poor data quality. Songwe differs from the other deposits in containing less LREE and higher relative amounts of the HREE reflecting with the identified late metasomatic growth of HREE enriched apatite.

The significant enrichment in the HREE that characterises the Lofdal mineralisation is conspicuous in Figure 22(b). These REE distributions are consistent with the revised interpretation (Swindon and Siegfried, 2011; Dodd et al., 2014) that most of the Lofdal carbonate "dykes" are hydrothermal rather than magmatic carbonatites - the HREE mineralisation being a consequence of metasomatic
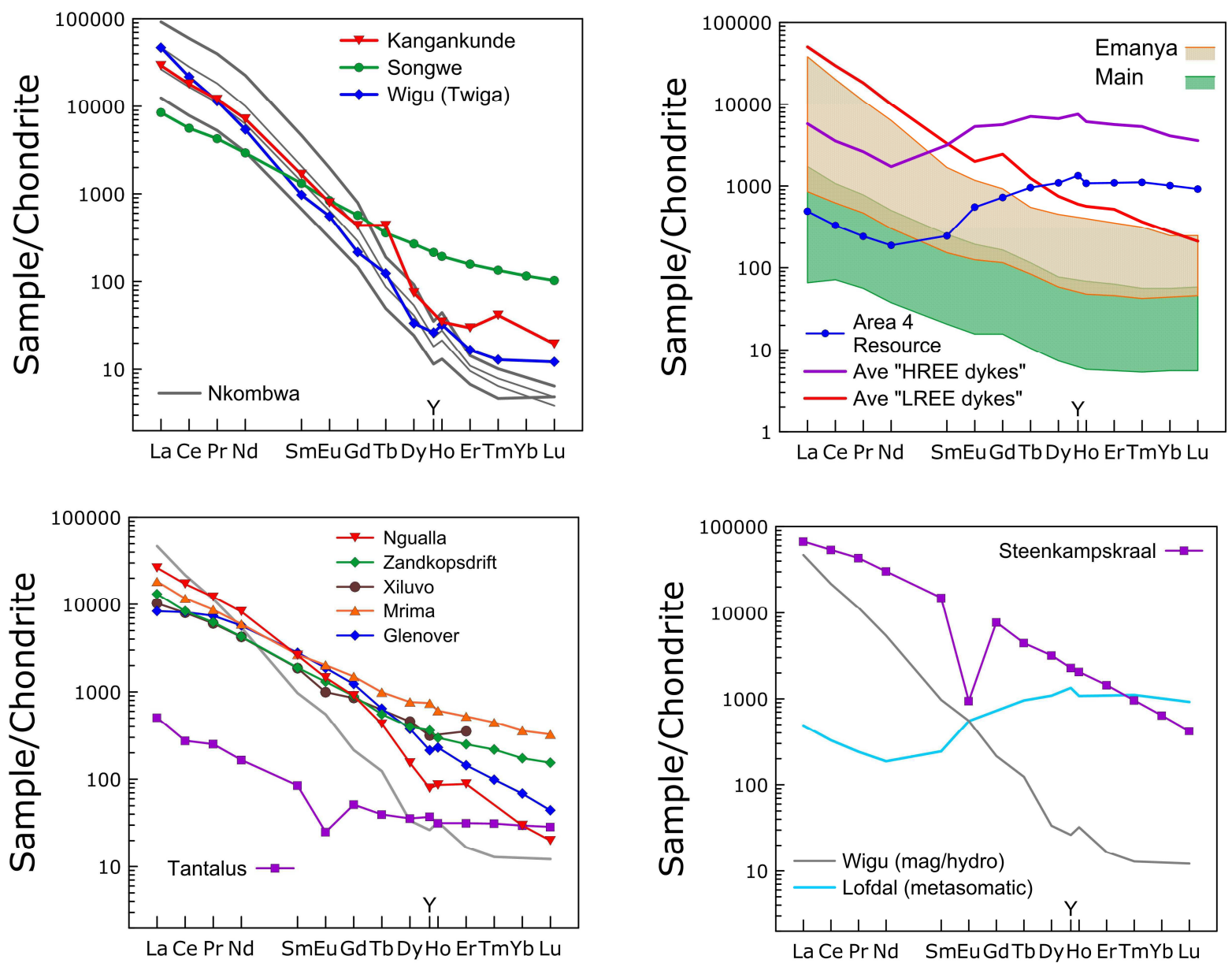

Figure 22: Chondrite - normalised plots of the resource REE distributions in African REE deposits. (a) Magmatic/hydrothermal carbonatitehosted deposits; Nkombwa traces are averages for all samples within the \%TREO ranges 1-3, 3-5, 5-10 and >10\%; (b) Lofdal hydrothermal deposit compared to REE in the Lofdal carbonatites and "dykes"; (c) Supergene laterite and ion-adsorbed clay deposits; Wigu for reference (d) Steenkampskraal monazite vein deposit (Wigu and Lofdal shown as reference). 
processes. Figure 22(b) compares the REE distribution in the Lofdal resource with the two carbonatite plugs - the Main and Emanya bodies - and averages representing "end member" compositions of the wide spectrum of carbonate "dyke" types in the swarm (data from Swinden and Siegfried, 2011). The Lofdal resource REE distribution is closely comparable to the "HREE-rich" end member dyke composition.

The normalised traces for the five supergene residual soil (laterite) deposits (Figure 22c) have similar levels of LREE to typical carbonatites but markedly elevated levels of the HREE.The reason can be appreciated with reference to Figure 21- deep weathering of un-evolved carbonatites (always the more voluminous) elevates REE concentration in the residual laterite through removal of the matrix constituents - a process that will not fractionate the LREE (with the possible exception of $\mathrm{Ce}$ ), relative to the HREE and so preserves the economically attractive LREE/HREE balance in mineralised laterite. The profile for the Tantalus ion-adsorbed clays is markedly different: in addition to the overall low TREO grade, the depletion in Eu is inherited from the granitic/syenitic protoliths. The profile also shows that the Tantalus clays are not unduly enriched in HREE: the key characteristic of the Longnan HREE-enriched type of adsorption clay deposits of southern China (Bao and Zhao, 2008).

Finally, Figure 22(d) reflects the high grade of the Steenkampskraal deposit relative to the other deposits while the prominent negative Eu anomaly in the MMZ is consistent with a crustal derivation of the mineralising fluid. Due to the high ore grade, concentrations of the key tradeable HREE Tb, Dy and Y are higher in the Steenkampskaal ore than at Lofdal.

\section{Acknowledgements}

The authors gratefully acknowledge the contribution of information and/or diagrams from several of the companies managing the projects discussed in this review. In particular, Jock Harmer would like to express his gratitude for the contributions made by Dave Hammond and Dr Wally Witt (Peak Resources), Tony Harwood, Paul Karpeta and Mike Evans (Montero Mining), Scott Swinden and Don Burton (Namibia Rare Earths), and Alex Andersson (Glenover); Paul Nex gratefully acknowledges the informative discussion with Cesare Morelli about Rainbow Minerals' accomplishments at Gakara. Any errors or inaccuracies in the final product are, however, entirely our responsibility. We are grateful to Julia Haddon for drafting the Songwe map and to Belinda Oosthuizen for the initial drafting of many of the other maps and sections.

The final version of this review was improved by thoughtful constructive reviews by Peter Siegfried and David Reid and editing by Mike Wilson.

\section{References}

Adamas Intelligence, 2014. http://www.adamasintel.com/Previews/ REMO_Executive_Summary.pdf

Al-Ali, S., Wall, F., Pascoe, R., Rollinson, G., Dawes, W. and Brady, A., 2014. Process mineralogical characteristics of REE-bearing carbonatite from the Songwe Hill deposit, Malawi. $21^{\text {st }}$ meeting of the International Mineralogical Association, Johannesburg, Abstract Volume, p 57.

Andreoli, M.A.G., Smith, C.B., Watkeys, M., Moore, J.M., Ashwal, L.D. and Hart, R.J., 1994. The geology of the Steenkampskraal Monazite Deposit, South Africa: Implications for REE-Th-Cu mineralization in charnockite-granulite terranes. Economic
Geology, 89, 994-1016.

Appleton, J. D., Bland, D. J., Nancarrow, P. H., Styles, M. T., Mambwe, S. H. and Zambezi, P., 1992. The occurrence of daqingshanite- $(\mathrm{Ce})$ in the Nkombwa Hill carbonatite, Zambia. Mineralogical Magazine, 56, 419-422.

Bao, Z. and Zhao, Z., 2008. Geochemistry of mineralization with exchangeable REY in the weathering crusts of granitic rocks in South China. Ore Geology Reviews, 33, 519-535.

Basson, I.J., Muntingh, A., Jellicoe, B.C. and Anthonissen, C.J., in press. Structural Interpretation of the Steenkampskraal Monazite Deposit, Western Cape, South Africa. Journal of African Earth Sciences, in press.

Brögger, W.C., 1921. Die Eruptivgesteine des Kristianiagebietes, IV., Das Fengebiet in Telemark. Norsk.Vidensk. Selsk. Skrifter, I, Math. Naturv. Kl., No 9, 1-408.

Broom-Fendley, S., Brady, A., Dawes, W., Wall, F., Gunn, G. and Horstwood, H., 2014a. The Songwe-Hill carbonatite, Malawi: new mapping, geochemistry and $\mathrm{U}-\mathrm{Pb}$ dating. $21^{\mathrm{st}}$ meeting of the International Mineralogical Association, Johannesburg, Abstract Volume, p195.

Broom-Fendley, S., Wall, F., Gunn, G., Andersen, J., Brady, A. and Dawes, W., 2014b. Late stage apatite: a potential heavy REEenriched co-product of light REE minerals in carbonatites. $21^{\text {st }}$ meeting of the International Mineralogical Association, Johannesburg, Abstract Volume, p57.

Buckley, H.A. and Woolley, A.R., 1990. Carbonates of the magnesitesiderite series from four carbonatite complexes. Mineralogical Magazine, 54, 413-418.

Cahen, L. and Snelling, N.J., 1966. The Geochronology of Equatorial Africa. North-Holland Publishing Company, Amsterdam.

Chi, R., Tian, J., (2008). Weathered Crust Elution-Deposited Rare Earth Ores. Nova Science Publishers, New York, 308 pp.

Clay, A.N., Machowski, R., Jones, I., Marra, G.L., Duke, V., Harper, F. and de Klerk, A.J., 2014. National Instrument 43-101, Independent Technical Report on the Results of a Feasibility Study for the Steenkampskraal Rare Earth Element Project in the Western Cape, South Africa for Great Western Minerals Group Ltd. NI 43- 101, Technical Report, pp 262. (available from www.sedar.com).

Connelly, N.G., Damhus, T., Hartshorn, R.M. and Hutton, A.T., 2005. Nomenclature of Inorganic Chemistry: IUPAC Recommendations 2005. RSC Publishing, pp 366.

Croll, R., Swinden, S., Hall, M., Brown, C., Beer. G., Scheepers, J., Redelinghuys, T., Wild, G. and Trusler, G.E., 2014. Mkango Resources Limited Songwe REE Project Malawi: NI 32-101, Prefeasibility Report. 382 pp. (available from www.sedar.com).

Deans, T. and McConnell, J.D.C., 1955. Isokite, CaMgPO4F, a new mineral from Northern Rhodesia. Mineralogical Magazine, 30, 681-690.

Desharnais, G., Camus, Y. and Bisaillon, C., 2014. NI 43-101, Technical Report: Resources for the Tantalus Rare Earth Ionic Clay Project,Northern Madagascar. SGS Technical report for Tantalus Rare Earths AG, 20 October 2014, 165pp.

Dodd, D.S., Hannon, P.J.F., Roy, W.D., Siegfried, P.R. and Hall, M.R., 2014. Preliminary economic assessment on/of the Lofdal rare earths project, Namibia. NI 43-101, Technical Report, pp 363. (available from www.sedar.com).

Duraiswami, R.A. and Shaikh, T.N., 2014. Fluid-rock interaction in the Kangankunde Carbonatite Complex, Malawi: SEM based evidence for late stage pervasive hydrothermal mineralisation. Central European Journal of Geosciences 6, 476-491.

Edgar, A.D., (1974). On the use of the term "Agpaitic". Mineral. Mag., 39, 729-730.

Estrade, G., Beziat, D., Salvi, S., Tiepolo, M., Paquette, J-L. and 
Rakotovao, S., 2014. Unusual evolution of silica-under-and oversaturated alkaline rocks in the Cenozoic Ambohimirahavavy Complex (Madagascar): Mineralogical and geochemical evidence. Lithos, 206-207, 361-383.

Frets, D.C., 1969. Geology and structure of the Huab-Welwitshia area South-West Africa. Chamber of Mines, Precambrian Research Unit, University of Cape Town Bulletin 5, pp235

Garson, M.S., 1965. Carbonatites in Southern Malawi. Geological Survey of Malawi, Bulletin, 15, pp128.

Garson, M.S., 1966. Carbonatites in Malawi. In: O.F.Tuttle and J. Gittins (eds.), "Carbonatites", 33-72, Interscience, pp 591.

Garson, M.S. and Campbell Smith, W., 1965. Carbonatitic and agglomeratic vents in the Western Shire Valley. Geological Survey of Malawi, Memoir 3, pp167.

Gilbertson, J., 2013. A competent persons report on the Tantalus project, northern Madagascar. Report for Tantalus Rare Earths AG by SRK Exploration, pp146.

Hawkesworth, C.J., Gledhill, A.R., Roddick, J.C., Miller, R. McG. and Kroner, A., 1983. Rb-Sr and 40Ar/39Ar studies bearing on thermal models for the thermal evolution of the Damara Belt, Namibia. In: Miller, R. McG. (Ed.). Evolution of the Damara Orogen of South-West Africa / Namibia. Geological Society of South Africa. Special Publication, 11, 323-338.

Hancox, P.J. and Jones, I., 2012. Resource Statement and Technical Report on the Steenkampskraal Monazite Property in the Western Cape Province, South Africa. NI 43-101, Technical Report, pp208. (available from www.sedar.com).

Hanson, R.E., Harmer, R.E. Blenkinsop, T.G. Bullen, D.S. Dalziel, I.W.D., Gose, W.A., Hall, R.P., Kampunzu, A.B., Key, R.M., Mukwakwami, J., Munyanyiwa, H., Pancake, J.A., Seidel, E.K. Ward E., (2006). Mesoproterozoic intraplate magmatism in the Kalahari Craton: A review. J. Afr. Earth Sci., 46, 141-167.

Harper, F., Venter, M., Hall, M., Siegfried, P., Brown, J., Stripp, G., e Jager, C., Scheepers, J., Wiid, G., Vivier, K. and Grobler, M., 2011. Amended Independent technical report on the results of a Preliminary economic assessment Of Frontier Rare Earths Rare Earths Project, located in the Northern Cape Province of South Africa. Venmyn Rand NI 43-101, report to Frontier Rare Earths: 30 March 2012, 104 pp. (available from www.sedar.com).

Harper, F., Njowa, G., Wiid, G., Vivier, J., Siegfried, P., Zietsman, R., Brown, J., Duke, V. and Hall, M., 2014. National Instrument 43101 - Independent Technical Report on the Results of a Preliminary Feasibility Study on the Zandkopsdrift Rare Earth Element and Manganese By-product Project in the Northern Cape Province of South Africa for Frontier Rare Earths Limited: Report: 2 June 2015, 226 pp. (available from www.sedar.com).

Hoatson, D.M., Jaireth, S. and Miezitis, Y., 2011. The major rare earth- element deposits of Australia: geological setting, exploration and resources. Geoscience Australia, 204 pp.

Hoffman, P.F., Hawkins, D.P., Isachsen, C.E. and Bowring, S.A., 1996. Precise U-Pb zircon ages for early Damaran magmatism in the Summas Mountains and Welwitshia inlier, northern Damara belt, Namibia. Communications of the Geological Survey of Namibia, $11,47-52$.

Holt, D.N., 1965. The Kangankunde Hill rare earth prospect. Bulletin, Geological Survey of Malawi, 20.

Joint Ore Reserve Committee., 2012. The JORC Code, 2012 Edition, Australasian Code for Reporting of Exploration Results,Mineral Resources and Ore Reserves, 44pp.

Jung, S., Hoffer, E. and Hoernes, S., 2007. Neo-Proterozoic rift-related syenites (Northern Damra Belt, Namibia): Geochemical and Nd$\mathrm{r}-\mathrm{Pb}-\mathrm{O}$ isotope constraints for mantle sources and petrogenesis. Lithos, 96, 415-435.

Karpeta, W.P, Harwood, R., Bucibo, S.,Kulwa, A. and Musengi, S.,
2012. The geology of the Wigu Hill Rare Earth-Carbonatite Complex. Unpublished Internal Report : Montero Mining Ltd., $42 \mathrm{pp}$.

Knoper, M.W., (2010).The Mesoproterozoic Steenkampskraal RareEarth Element deposit in Namaqualand, South Africa. 2010. GSA, Denver Annual Meeting (31 October -3 November 2010); Paper No. 132-134.

Kynicky, J., Smith, M.P. and Xu, C., 2012. Diversity of rare earth deposits: The key example of China. Elements, 8, 361-367.

Le Maitre, R.W., (Editor), Streckeisen, A., Zanettin, B., Le Bas, M.J., Bonin, B., Bateman, P., Bellieni, G., Dudek, A., Efremova, S., Keller, J., Lameyre, J., Sabine, P.A., Schmid, R., Sørensen, H., Woolley. A.R., 2002. Igneous rocks: A Classification and Glossary of Terms. Cambridge University Press, 236pp.

Linnen, R.L., Samson, I.M., Williams-Jones, A.E. and Chakhmouradian, A.R., 2014. Geochemistry of the rare-earth element, $\mathrm{Nb}, \mathrm{Ta}, \mathrm{Hf}$, and $\mathrm{Zr}$ deposits. In: Scott, S.D. (Ed.). Treatise on Geochemistry ( $2^{\text {nd }}$ edition), Volume 13 , Geochemistry of Mineral Deposits, 543-568.

Loye, E.R., (2014). The Geological Controls on the heavy rare earth element enriched alteration zone of Area 4, Lofdal, Khorixas, Namibia. Unpubl. MSc., Camborne School of Mines, University of Exeter, 114 p.

Lynas Corporation Ltd., 2010. Lynas receives approval from the Government of Malawi to complete the acquisition of rare earths resource. Press Release 22 $2^{\text {nd }}$ December 2010, pp 5. (https:// www.lynascorp.com/Announcements/2010/Malawi_Completion_Announcement_Final_221210_928080.pdf).

Mitchell, R.H. and Liferovich, R.P., (2006). Subsolidus deuteric/ hydrothermal alteration of eudialyte in lujavrite from the Pilanesberg alkaline complex, South Africa. Lithos, 91, 352372.

Montero Mining, (2013). Montero Revises High-Grade REE Resource in the Twiga Zone to 0.47 Million Tonnes Averaging 5.2\% LREO5 at the Wigu Hill Rare Earth Project in Tanzania: press release 6 August 2013: (http://newsroom.monteromining.com/press releases/montero-revises-high-grade-ree-resource-in-thetwigazone-to-0-47- million-tonnes-tsx-venturemon-2013080608 90542001).

Moore, A.E. and Verwoerd, W.J., 1985. The olivine melilitite"kimberlite"-carbonatite suite of Namaqualand and Bushmanland, South Africa. Trans. Geol. Soc. S. Afr, 88, 281-294.

Nakai, S., Masuda, A. and Lehmann, B., 1988. La-Ba dating of bastnaesite. American Mineralogist, 73, 1111-1113.

Northrup, W., Mossop, A., Carter, T. and Deiss, A., 2011. National Instrument, 43-101, Technical Report for the Initial Niobium Resource Estimate - Mrima Hill Rare Earth/Niobium Project in South Kenya. 295p. (available from www.sedar.com).

Olivo, G.R. and Williams-Jones, A.E., (1999). Hydrothermal REErich eudialyte from the Pilanesberg Complex, South Africa. Can. Min., 37, 653-663.

Peak Resources, 2013. Increased Resource Estimate To Improve Ngualla Project Economics: Report to the ASX, 4 April 2013.

Peak Resources, 2014a. Ngualla Rare Earth Project: Preliminary Feasibility Study; Executive Summary. Report to the ASX, 19 March 2014.

Peak Resources, 2014b. Ngualla Rare Earth Project - Maiden Ore Reserve. Report to the ASX, 19 March 2014.

Pollard, B. and Mapleson, D., 2013. NI 43-101, Technical Report for the Mrima Hill Niobium and Rare Earth Project, Kwale District, Kenya.169p. (available from www.sedar.com).

Rainbow Rare Earths, 2014. Developing the world's richest rare earth deposit: near term, low cost production. Factsheet on http:// www.rainbowrareearths.com. 
Siegfried, P. and Hall, M., 2012. NI 43-101, Technical report and June 2016, 406, mineral resource estimate for area 4 of the Lofdal rare earth element (REE) project, Khorixas District, Republic of Namibia. MSA Group, NI 43-101, Technical Report to Namibia Rare Earths Ltd. (available from www.sedar.com).

Snelling, N.J., 1962. Age Determination Unit. Overseas Geological Surveys, Report for 1960-61, 27-35.

Snelling, N.J., 1965. Age determinations on three African carbonatites. Nature, 205, 491.

Sørenson, H., 1997. The Agpaitic Rocks - An Overview. Mineralogical Magazine, 61, 485-498.

Swinden, S. and Siegfried, P., 2011. Amended 43-101, Technical Report on the Rare Earth Occurrences in the Lofdal Carbonatite Complex, Kunene Region, Khorixas District, Namibia; prepared for Namibia Rare Earths Inc. 210pp. (available from www.sedar.com).

Swinden, S. and Hall, M., 2012. NI 43-101, Technical report and mineral resource estimate for the Songwe Hill rare earth element (REE) project, Phalombe District, Republic of Malawi. MSA Group NI 43-101, Technical Report to Mkango Resources, pp168. (available from www.sedar.com).

Turner, D.C., Andersen, L.S., Punukollu, S.N., Silwa, A and Tembo, F., 1989. Igneous phosphate resources in Zambia. In: Notholt, A.J.G., Sheldon, R.P. and Donaldson, D.F., (eds.). Phosphate deposits of the world, 2. Phosphate rock resources. Cambridge University Press, 247-257.

Venter, M., Hall, M. and Siegfried, P., 2010. NI 43-101, Resource Estimate and Technical Report on the Zandkopsdrift Rare Earth Element (REE) Project, located in the Republic of South Africa. MSA Group NI 43-101, report to Frontier Rare Earths Ltd. 28 September 2010, 185pp. (available from www.sedar.com).

Verwoerd, W.J., 1967. The carbonatites of South Africa and South West Africa. South Africa Geological Survey Handbook, v. 6, $452 \mathrm{p}$.

Verwoerd, W.J., 1986. Mineral deposits associated with carbonatites and alkaline rocks. In: Anhaeusser, C.R. and Maske, S. (eds.): Mineral Deposits of Southern Africa, II, Geological Society of South Africa, Johannesburg, 1041-1060.

Verwoerd, W.J., 1993. Update on carbonatites of South Africa and

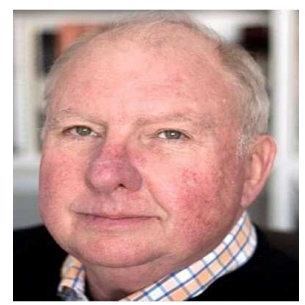

Jock Harmer holds an MSc in Geology from the University of Natal and a PhD in Geochemistry from the University of Cape Town. Jock's initial career was in academia, holding research and teaching positions at the CSIR, the University of Pretoria and the Council for Geoscience. Joining the minerals industry in 2002 he served as Exploration Manager for 2 junior PGE explorers and since early 2007 operated as an independent private consultant working on contracts exploring for platinum group metals, base metals and the rare earth elements in Africa, India and Greenland. In May 2015 he returned to academia as Professor of Exploration Geology and Director of the MSc Program in Exploration and Economic Geology at Rhodes University.
Namibia. South African Journal of Geology, 96, 75-95.

van Wambeke, L., 1977. The Karonge rare earth deposits, Republic of Burundi: new mineralogical - geochemical data and origin of mineralization. Mineralium Deposita, 12, 373-380.

Wall, F., 2004. An illustration of the evolution and alteration of carbonatites using REE, Sr-rich carbonatites at Nkombwa, Zambia. In Vladykin, N.V. and Vinogradova A.P., (eds.): Deepseated magmatism: Its sources and their relation to plume processes, 48-67.

Wall, F. and Mariano, A.N., 1996. Rare earth minerals in carbonatites: a discussion on the Kangankunde carbonatite, Malawi. In: Jones, A.P., Wall, F. and Williams, C.T., (eds.). Rare Earth Minerals: Chemistry, Origin and Ore Deposits. Chapman and Hall, 193225.

Wall, F., Niku-Paavola, V.N., Storey, C., Muller, A. and Jeffries, T., 2008. Xenotime-(Y) from carbonatite dykes at Lofdal, Namibia: unusually low LREE-HREE ratio in carbonatite, and the first dating of xenotime overgrowths on zircon. Canadian Mineralogist 46, 861-877.

Witt, W.K., Hammond, D.P. and Townend, R., 2013. The Ngualla Rare Earth Element Deposit, Tanzania. Abstract: SGA Conference, Uppsala.

Witt, W.K., Hammond, D.P. and Townend, R., 2014. The Ngualla Rare Earth Element Deposit, Tanzania. In: N. Ilbeyli and M. Gurhan Yalcin (eds.): Abstract Volume: $30^{\text {th }}$ International Conference on "Ore Potential of Alkaline, Kimberlite and Carbonatite Magmatism", Antalya, Turkey, 224-227.

Woolley, A.R., 1989. The spatial and temporal distribution of carbonatites. In Bell, K. (ed.). Carbonatites - Genesis and Evolution, 15-37, Allen and Unwin, London.

Woolley, A.R., 1991. The Chilwa Alkaline Igneous Province of Malawi: A Review. In: Kampunzu, A.B. and Lubala, R.T., (eds.). Magmatism in Extensional Structural Settings: The Phanerozoic African Plate. Springer-Verlag, Berlin, 377-409.

Woolley, A.R., 2001. Alkaline Rocks and Carbonatites of the World: Part 3 Africa. The Geological Society, London, pp372.

Woolley, A.R. and Buckley, H.A., 1993. Magnesite-siderite series carbonates in the Nkombwa and Newania carbonatite complexes. South African Journal of Geology, 96, 126-130.

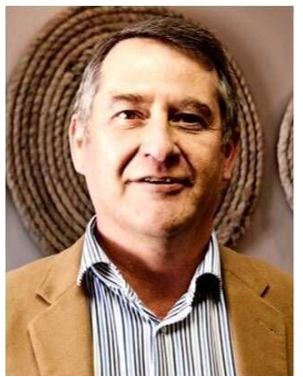

Paul Nex obtained a first-class BSc (Honours) degree in Earth Science from Oxford Brookes University in 1991 and a PhD for his research on uranium mineralisation in sheeted leucogranites in Namibia from the National University of Ireland in 1997. His current research interests are in critical metals, particularly antimony and rare earth elements, uranium mineralisation in Namibia and mineralisation in the Bushveld Complex. 